\title{
Facile synthesis of graphene wool doped with oleylamine-capped silver nanoparticles (GW-aAgNPs) for water treatment applications
}

\author{
Adedapo O. Adeola ${ }^{1}$ - Gugu Kubheka ${ }^{1}$ - Evans M. N. Chirwa ${ }^{2}$ Patricia B. C. Forbes ${ }^{1}$
}

Received: 27 July 2021 / Accepted: 6 September 2021 / Published online: 8 October 2021

(c) The Author(s) 2021

\begin{abstract}
The facile synthesis of graphene wool doped with oleylamine-capped silver nanoparticles (GW- $\alpha \mathrm{AgNP})$ was achieved in this study. The effect of concentration, $\mathrm{pH}$, temperature and natural organic matter (NOM) on the adsorption of a human carcinogen (benzo(a)pyrene, BaP) was evaluated using the doped graphene wool adsorbent. Furthermore, the antibacterial potential of GW- $\alpha$ AgNP against selected drug-resistant Gram-negative and Gram-positive bacteria strains was evaluated. Isotherm data revealed that adsorption of $\mathrm{BaP}$ by $\mathrm{GW}-\alpha \mathrm{AgNP}$ was best described by a multilayer adsorption mechanism predicted by Freundlich model with least ERRSQ $<0.79$. The doping of graphene wool with hydrophobic AgNPs coated with functional moieties significantly increased the maximum adsorption capacity of GW- $\alpha$ AgNP over GW based on the $q_{\max }$ and $q_{m}$ predicted by Langmuir and Sips models. $\pi-\pi$ interactions contributed to sorbent-sorbate interaction, due to the presence of delocalized electrons. GW- $\alpha \mathrm{AgNP}-\mathrm{BaP}$ interaction is a spontaneous exothermic process (negative $\Delta H^{\circ}$ and $\Delta G$ ), with better removal efficiency in the absence of natural organic matter (NOM). While GW is more feasible with higher maximum adsorption capacity $\left(q_{m}\right)$ at elevated temperatures, GW- $\alpha$ AgNP adsorption capacity and efficiency is best at ambient temperature, in the absence of natural organic matter (NOM), and preferable in terms of energy demands and process economics. GW- $\alpha$ AgNP significantly inhibited the growth of Gram-negative Pseudomonas aeruginosa and Gram-positive Bacillus subtilis strains, at $1000 \mathrm{mg} / \mathrm{L}$ dosage in preliminary tests, which provides the rationale for future evaluation of this hybrid material as a smart solution to chemical and microbiological water pollution.
\end{abstract}

Keywords Adsorption $\cdot$ Antimicrobial property $\cdot$ Graphene wool composite $\cdot$ Silver nanoparticles $\cdot$ Water treatment

\section{Introduction}

Benzo(a)pyrene $(\mathrm{BaP})$ is regarded as one of the most hazardous environmental pollutants exhibiting both genotoxic and carcinogenic toxicity in humans according to the International Agency for Research on Cancer (IARC) (IARC 2010; Hardonnière et al. 2016). BaP belongs to the group of ubiquitous emerging chemical pollutants (ECPs) known as polycyclic aromatic hydrocarbons (PAHs) (Adeola \& Forbes 2020; Munyeza et al. 2020). BaP is persistent in the

Patricia B. C. Forbes

patricia.forbes@up.ac.za

1 Department of Chemistry, Faculty of Natural and Agricultural Sciences, University of Pretoria, Lynnwood Road, Hatfield, Pretoria 0002, South Africa

2 Water Utilisation and Environmental Engineering Division, Department of Chemical Engineering, University of Pretoria, Lynnwood Road, Hatfield, Pretoria 0002, South Africa environment and poses health risk due to its recalcitrance to biodegradation (Yerushalmi et al. 2006). The maximum acceptable concentration (MAC) of PAHs in surface water is $0.01 \mu \mathrm{g} / \mathrm{L}$; however, several reports suggest that BaP levels detected in South Africa are higher than the MAC value, thus posing a potential health risk (Adeniji et al. 2019).

Furthermore, the adaptive resistance of several bacteria to antibiotics, such as chloramphenicol, penicillin, etc., has led to the interesting discovery that silver nanoparticles can inhibit microbial growth and may be lethal against drugresistant bacteria (Anthony et al. 2014; McBirney et al. 2016; Huang et al. 2017). Advances in research into a hybrid approach to environmental protection and remediation have brought about the need for the development of "smart" materials/composites with multifunctional capabilities for improved efficiency and process economics (Bezza and Chirwa 2016; Miren et al. 2018; Adeola \& Forbes 2021b). Several materials with antimicrobial properties have been developed for the removal of pollutants in aqueous matrices, 
examples of such materials are polyanilineTi(IV)arsenophosphate (Bushra et al. 2014), iron and manganese coated silica gel (Ahmad et al. 2015), chitosan doped with silver nanoparticles (Ishihara et al. 2015), nano-silver-supported activated carbon (Eltugral et al. 2016), graphene foam $/ \mathrm{TiO}_{2}$ nanosheet hybrids (Wang et al. 2017), iron nanoparticles (Da'na et al. 2018), silk fiber doped with tannic acid (Zhang et al. 2019), antimicrobial polymer (Li et al. 2020) chitosan/ nitrogen-doped graphene quantum dots (Amari et al. 2021), etc. The design of composites has reportedly enhanced physicochemical properties of adsorbents such as specific surface area, stability, conductivity, tensile strength, chemical robustness, charge mobility, flexibility, thin-film thickness, and provided a basis for the growing interest in the utilization of composites for water treatment applications (Adeola $\&$ Forbes 2021b).

A comprehensive risk-based assessment of graphenebased composites is currently unavailable; however, it is assumed that the composites may not pose a significant health risk based on their composition, but their lightweight nature may pose inhalation risks (Schinwald et al. 2012). Thus, the physical structure of the graphene-based material and the fabrication method is critical. With respect to graphene wool doped with oleylamine-capped silver nanoparticles (GW- $\alpha$ AgNPs), the quartz wool substrate acts as a solid support, assisting with immobilization of the graphene and silver nanoparticles. Furthermore, unlike most composites generated in the form of flakes and powder, GW- $\alpha$ AgNPs presents a wool-like form that may be more suitable as a packing material for filters and other water polishing tools.

The overall aim of this study was to synthesize a composite of graphene wool and silver nanoparticles (GW- $\alpha$ AgNPs) with antibacterial activity, for the removal of a human carcinogen, namely benzo(a)pyrene, from polluted water. The influence of process variables such as $\mathrm{pH}$, temperature, and initial concentration of $\mathrm{BaP}$ on the sorption mechanism was established for optimum efficiency of the composite. Furthermore, the antibacterial activity of the composite was tested and is discussed briefly for potential dual application toward water treatment.

\section{Experimental methods}

\section{Chemicals}

Neat standard (98\% purity) of benzo(a)pyrene (BaP) was purchased from Supelco (USA). Sodium azide $\left(\mathrm{NaN}_{3}\right)$, silver nitrate $\left(\mathrm{AgNO}_{3}, 99.9 \%\right)$, oleic acid (99\%), oleylamine (99\%), phenyl ether (99\%), and Tryptic Soybean Broth (TSB) were purchased from Sigma-Aldrich (Germany). Nitric acid $\left(\mathrm{HNO}_{3}\right)$, hydrochloric acid $(\mathrm{HCl})$, sodium chloride $(\mathrm{NaCl})$, sodium hydroxide $(\mathrm{NaOH})$, ethanol $(\mathrm{EtOH})$, hexane, and calcium chloride $\left(\mathrm{CaCl}_{2}\right)$ were purchased from Associated Chemical Enterprises (ACE, Johannesburg, South Africa). 9-30 $\mu \mathrm{m}$ coarse quartz wool (Arcos Organics, New Jersey, USA), argon, and hydrogen $(99.999 \%$, Afrox, South Africa) were purchased for GW synthesis. Sterile syringe filters ( $33 \mathrm{~mm}$ diameter) with a $0.22 \mu \mathrm{m}$ pore size containing a hydrophilic polyethersulfone (PES) membrane were purchased from Merck (Darmstadt, Germany). The antibacterial tests were carried out using model Gram-negative Pseudomonas aeruginosa CB1 and Gram-positive Bacillus subtilis $\mathrm{CN} 2$ bacterial strains that had been previously isolated and deposited in the GenBank database under the accession numbers KP793922 and KP7939228, respectively (Bezza and Chirwa 2016). All the solutions were prepared with de-ionized water (DI, $9.2 \mu \mathrm{S} / \mathrm{cm}^{3}$ ) obtained from a Milli-Q water purification system (Millipore, Bedford, MA, USA).

\section{Facile synthesis of GW-aAgNPs}

Graphene wool was synthesized using the chemical vapor deposition method on a quartz wool substrate whereby an optimized stream of argon, hydrogen, and methane gas was temperature ramped to $1200{ }^{\circ} \mathrm{C}$ as previously described (Adeola \& Forbes 2019, 2020; Schoonraad et al. 2020). Lipopeptide-coated silver nanoparticles were synthesized in phenyl ether with oleylamine and oleic acid as both reducing agents and capping agents (Liu et al. 2011; Sha et al. 2011; Çınar et al. 2011).

The composite was prepared as follows: Briefly, GW $(200 \mathrm{mg})$ and DI water $(100 \mathrm{~mL})$ were added into a sealed bottle $(250 \mathrm{~mL})$ and stirred gently for $1 \mathrm{~h}$ using a magnetic stirrer, before the addition of the dopant mixture. Ag nanoparticles $(300 \mathrm{mg})$ dispersed in diphenyl ether $(100 \mathrm{~mL})$ were added into the GW solution and stirred for $12 \mathrm{~h}$ at room temperature under argon, to ensure that AgNPs coordinated with graphene wool at the water/diphenyl ether interface. The GW- $-\alpha$ AgNP composite was rinsed with acetone and centrifuged at $6000 \mathrm{rpm}$ for $10 \mathrm{~min}$, three times consecutively. The obtained GW- $\alpha$ AgNP composites were then washed with hexane to remove residual oleylamine. The final $\mathrm{GW}-\alpha \mathrm{AgNP}$ composite was freeze-dried for $48 \mathrm{~h}$. The facile synthesis is illustrated in Scheme 1.

\section{Characterization of the synthesized adsorbent}

The morphology of GW and GW- $\alpha$ AgNPs was examined by a combination of techniques including scanning electron microscopy (SEM), with images obtained from a Zeiss Ultra-Plus 55 field emission scanning electron microscope (FE-SEM), operated at $2.0 \mathrm{kV}$ (Zeiss, Germany). High-resolution transmission electron microscopy (TEM) images of capped-AgNPs and GW- $\alpha$ AgNPs were taken using a JEOL 


\section{PHASE 1}
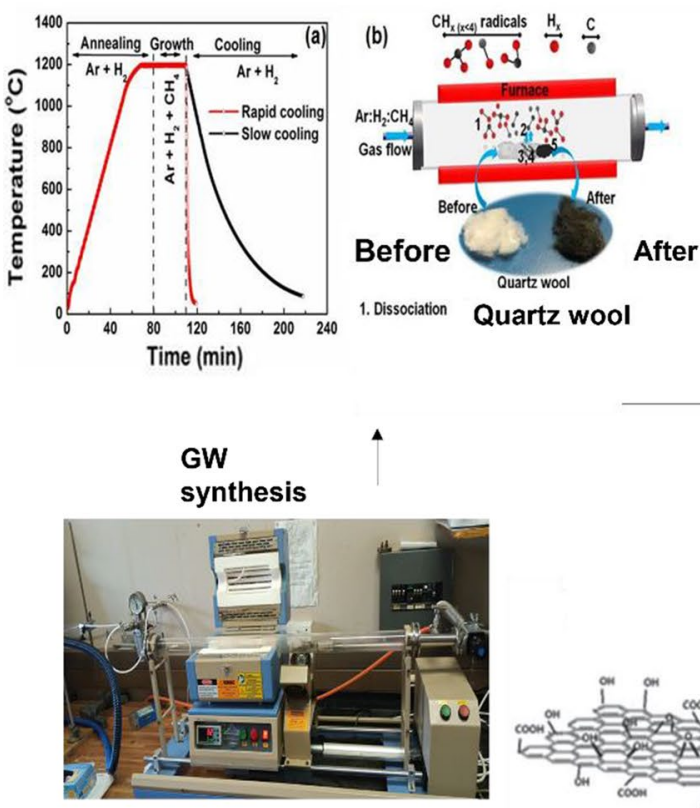

CVD instrument

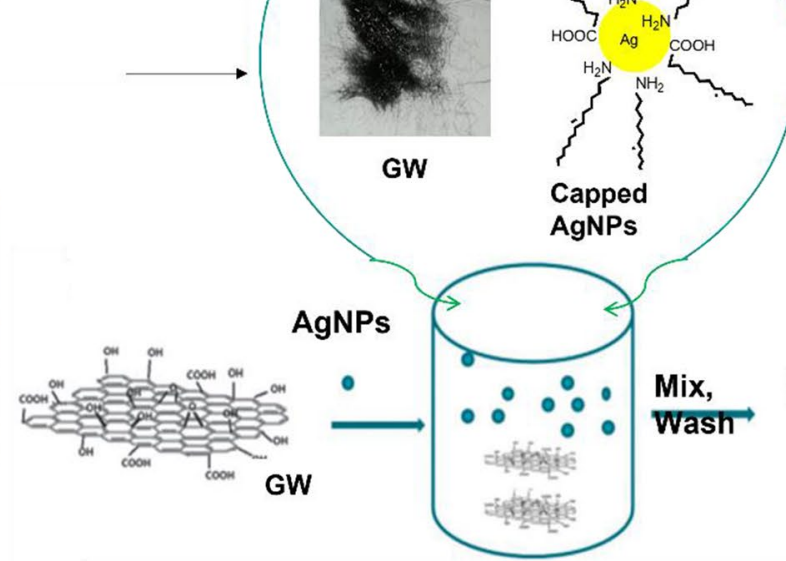

PHASE 3

\section{PHASE 3}

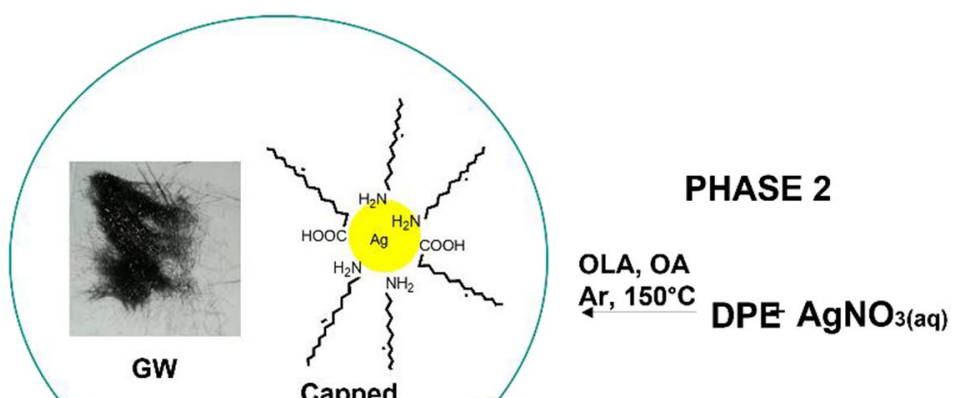

Scheme 1 Illustration of the synthetic route to graphene wool-silver nanoparticles composite

JEM 2100F (JOEL Ltd, Tokyo, Japan) operated at $200 \mathrm{kV}$ and equipped with an energy dispersive X-ray spectrometer (EDS) (OXFORD Link-ISIS-300 Zeiss, Germany). The specific surface area (SSA) of GW was determined using the modified Sears' method (Sears 1956; Adeola \& Forbes 2019). FTIR spectra of GW, capped AgNPs and GW$\alpha$ AgNPs were obtained using a Bruker Alpha-T spectrometer (Bruker Optik GmbH, Ettlingen, Germany). Elemental analysis of natural organic matter (NOM) was examined using inductively coupled plasma-optical emission spectrometry (ICP-OES, Spectro Arcos model, Thermo Fisher Scientific, South Africa). The conductivity of the background electrolyte was confirmed using an Orion Star A112 conductivity benchtop meter (Thermo Scientific, South Africa), and $\mathrm{pH}$ was monitored using a 780-pH meter (Metrohm Herisau, Switzerland).

\section{Sorption isotherm experiments}

Batch adsorption experiments of $\mathrm{BaP}$ onto $\mathrm{GW}$ and GW- $\alpha$ AgNPs were carried out in $40 \mathrm{~mL}$ PTFE screw cap amber vials (Stargate Scientific, South Africa) at $25 \pm 1{ }^{\circ} \mathrm{C}$ in a thermostated shaking water bath (Wisebath, Celsius Scientific, South Africa). Background electrolyte $(\mathrm{pH}=7.0)$ contained $0.01 \mathrm{~mol} / \mathrm{L} \mathrm{CaCl}_{2}$ (ACE, South Africa) in DI water with $200 \mathrm{mg} / \mathrm{L}$ of sodium azide (Sigma-Aldrich, Germany) as a biocide. The isotherm experiment was conducted with initial concentrations of the $\mathrm{BaP}$ solutions ranging from $100 \mu \mathrm{g} / \mathrm{L}$ to $500 \mu \mathrm{g} / \mathrm{L}$. The BaP desorption isotherm was examined by the addition of $5 \mathrm{~mL}$ fresh electrolyte with equilibration for $24 \mathrm{~h}$, after decanting the adsorption supernatant as previously described (Wang et al. 2008; Adeola \& Forbes 2021a). Adsorption isotherms of BaP were also performed at varying temperatures of 25,35 , and $45^{\circ} \mathrm{C}$ using a thermostated shaking water bath (Wisebath, Celsius Scientific, South Africa) to determine adsorption thermodynamics. The role of solution $\mathrm{pH}$ was evaluated by $\mathrm{pH}$ adjustment with $0.1 \mathrm{M} \mathrm{HCl}$ (Merck, South Africa) or $\mathrm{NaOH}$ (ACE, South Africa) over the $\mathrm{pH}$ range from 2 to 12 , to elucidate the $\mathrm{pH}$ effect on the removal of $\mathrm{BaP}$ from aqueous solution.

\section{Quantification}

After equilibration, centrifugation of the vials was performed at $6000 \mathrm{rpm}$ for $10 \mathrm{~min}$ to recover a clear supernatant. BaP concentrations were analyzed in triplicate $(n=3)$ by fluorescence spectroscopy (Horiba Jobin Yvon Fluoromax-4 spectrofluorometer). For all fluorescence measurements, the excitation and quantification emission wavelengths were at 330 and $464 \mathrm{~nm}$, while the excitation and emission slit widths were set at $5 \mathrm{~nm}$. The regression coefficient $\left(R^{2}\right)$ of the calibration curve was obtained from working solutions in the range of $100 \mu \mathrm{g} / \mathrm{L}$ to $500 \mu \mathrm{g} / \mathrm{L}$ of BaP and blanks were included for both calibration and sorption

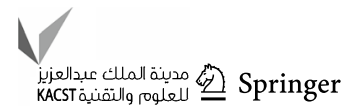


experiments. The equilibrium concentration $\left(C_{e}, \mu g / L\right)$ was deduced from the calibration equation. The amount of solute adsorbed $\left(\mathrm{q}_{\mathrm{e}}, \mu \mathrm{g} / \mathrm{g}\right)$ was extrapolated using a mass-balance equation (Eq. 1) and removal efficiency was estimated using Eq. 2:

$q_{e}=\frac{\left(C_{0}-C_{e}\right) V_{0}}{S_{m}}$

where $C_{o}(\mu \mathrm{g} / \mathrm{L})$ is the initial concentration, $\mathrm{C}_{\mathrm{e}}(\mu \mathrm{g} / \mathrm{L})$ is the equilibrium solute concentration, $\mathrm{V}_{\mathrm{o}}$ is the initial volume $(\mathrm{L})$ and $\mathrm{S}_{\mathrm{m}}$ is the mass $(\mathrm{g})$ of the adsorbent.

Removal efficiency $(\%)=\frac{\left(C_{0}-C_{e}\right)}{C_{0}} \times 100$

\section{Antibacterial test of GW- aAgNPs}

Sterilization of all glassware and media was carried out in an autoclave at $121^{\circ} \mathrm{C}$ for $15 \mathrm{~min}$. A facile test was conducted of bacteria inhibition of GW- $\alpha$ AgNP against model Gramnegative and Gram-positive bacteria strains (Pseudomonas aeruginosa $\mathrm{CB} 1$ and Bacillus subtilis $\mathrm{CN} 2$ ) previously isolated in our laboratory (Bezza et al., 2020). The inocula of $P$. aeruginosa and B. subtilis were cultured overnight in Tryptic Soybean Broth (TSB) under aerobic conditions at $37^{\circ} \mathrm{C}$. The inhibitory concentration of the composite against visible growth of $P$. aeruginosa and B. subtilis after $24 \mathrm{~h}$ of incubation at $37^{\circ} \mathrm{C}$ was investigated. Concentrations ranging from $0-1000 \mathrm{mg} / \mathrm{L}$ of GW- $\alpha \mathrm{AgNP}$ were prepared in sterilized conical flasks containing $100 \mathrm{~mL}$ TSB. Thereafter each flask was inoculated with $10 \mu \mathrm{L}$ of the cultured inoculum. Optical density measurements were taken after the incubation period. Experiments were conducted in duplicate and controls containing nutrient broth inoculated with inoculum without the inclusion of GW- $\alpha$ AgNPs. Bacteria concentration was estimated in relation to absorbance/optical density at $600 \mathrm{~nm}\left(\mathrm{OD}_{600}\right)$ using a UV/Vis spectrophotometer (Shimadzu UV-1800, Labotec, South Africa) and corrected by subtracting the background absorbance of the control (Anthony et al. 2014; Bezza et al. 2020).

\section{Results and discussion}

\section{Adsorbent characterization}

The morphology of the synthesized composite was examined using SEM and TEM (Fig. 1a and b). The high-resolution images revealed a heterogeneous surface structure with extensive coverage of GW with AgNPs. The oleylaminecapped AgNPs were analyzed with TEM prior to conjugation with GW, and spherical particles with a mean diameter of $12.67 \pm 3.9 \mathrm{~nm}$ were estimated via particle size analysis using the ImageJ software (Fig. $1 \mathrm{~b}$ and d). Qualitative analysis of GW- $\alpha \mathrm{AgNP}$ using EDS confirmed the presence and relative abundance of silver and carbon (Fig. 1c). FTIR (Fig. 1e and f) revealed two prominent peaks associated with the $\mathrm{sp}^{2}$ hybridized $\mathrm{C}=\mathrm{C}$ backbone of graphene and a broad peak of $\mathrm{Si}-\mathrm{O}-\mathrm{C}$ of functionalized quartz wool $\left(\mathrm{SiO}_{2}\right)$ coated with graphene at 775 and $1059 \mathrm{~cm}^{-1}$, respectively (Adeola \& Forbes 2020). Bands at 2921, 2856, 1631, $1450 \mathrm{~cm}^{-1}$ regions arising from $\mathrm{C}-\mathrm{H}, \mathrm{C}=\mathrm{O}, \mathrm{C}-\mathrm{N}$ stretching vibrations were observed in GW- $\alpha \mathrm{AgNP}$, respectively (Fig. 1e). Figure $1 \mathrm{f}$ revealed that several functional groups enhanced the stability of AgNPs and facilitated coordination with GW (Jyoti et al. 2016). The bands at 3325, 2921, 2856, 1743, $1631,1450,1377,1240,1043$ and $460 \mathrm{~cm}^{-1}$ correspond to $\mathrm{N}-\mathrm{H}, \mathrm{C}-\mathrm{H}, \mathrm{C}-\mathrm{C}, \mathrm{C}=\mathrm{O}, \mathrm{C}-\mathrm{N}, \mathrm{C}=\mathrm{N}$, and $\mathrm{Ag}-\mathrm{O}$ stretching, respectively, indicating the presence of oleylamine/oleic acid as the capping agent of silver nanoparticles (Mojahed et al. 2011; Prakash et al. 2013; Tran \& Jeong 2015).

\section{Sorption isotherm experiments}

Adsorption isotherm models are used to investigate the nature of sorbent-sorbate interactions of adsorption (Wang et al. 2018; Zhang et al. 2019; Adeola \& Forbes 2021a). Linear regression and nonlinear isotherm models such as Linear (Eq. 3), Freundlich (Eq. 4), Langmuir (Eq. 5), and Sips model (Eq. 6) were used to fit adsorption experimental data. The Error Sum of Squares (ERRSQ) (Eq. 7) was used to test all models used in this study.

$\mathrm{q}_{\mathrm{e}}=\mathrm{K}_{\mathrm{d}} \mathrm{C}_{\mathrm{e}}$

$\mathrm{q}_{\mathrm{e}}=\mathrm{K}_{\mathrm{F}} \mathrm{C}_{\mathrm{e}}^{\mathrm{N}}$

$\mathrm{q}_{\mathrm{e}}=\frac{\mathrm{q}_{\max } \mathrm{K}_{\mathrm{L}} \mathrm{C}_{\mathrm{e}}}{1+\mathrm{K}_{\mathrm{L}} \mathrm{C}_{\mathrm{e}}}$

$\mathrm{q}_{\mathrm{e}}=\frac{q_{m} \mathrm{~K}_{\mathrm{s}} \mathrm{C}_{\mathrm{e}}^{\mathrm{ms}}}{1+\mathrm{K}_{\mathrm{s}} \cdot \mathrm{C}_{\mathrm{e}}^{\mathrm{ms}}}$

$\sum_{\mathrm{i}=1}^{\mathrm{n}}\left(\mathrm{q}_{\mathrm{e}, \mathrm{cal}}-\mathrm{q}_{\mathrm{e}, \exp }\right)_{\mathrm{i}}^{2}$

where $\left.K_{F}(\mathrm{mg} / \mathrm{g})(\mathrm{L} / \mathrm{mg})^{\mathrm{N}}\right)$ and $N$ (dimensionless) is the Freundlich constant and intensity parameter, an indicator of site energy heterogeneity; $q_{\max }(\mathrm{mg} / \mathrm{g})$ and $K_{\mathrm{L}}(\mathrm{L} / \mathrm{mg})$ are the Langmuir maximum adsorption capacity and Langmuir constant associated with solute-surface interaction energy, respectively; $K_{s}(\mathrm{~L} / \mathrm{mg})$ and $q_{\max }(\mathrm{mg} / \mathrm{g})$ are Sips isotherm model constants and maximum adsorption capacity and $m s$ is Sips isotherm exponent; $q_{e}$ is the solid-phase 


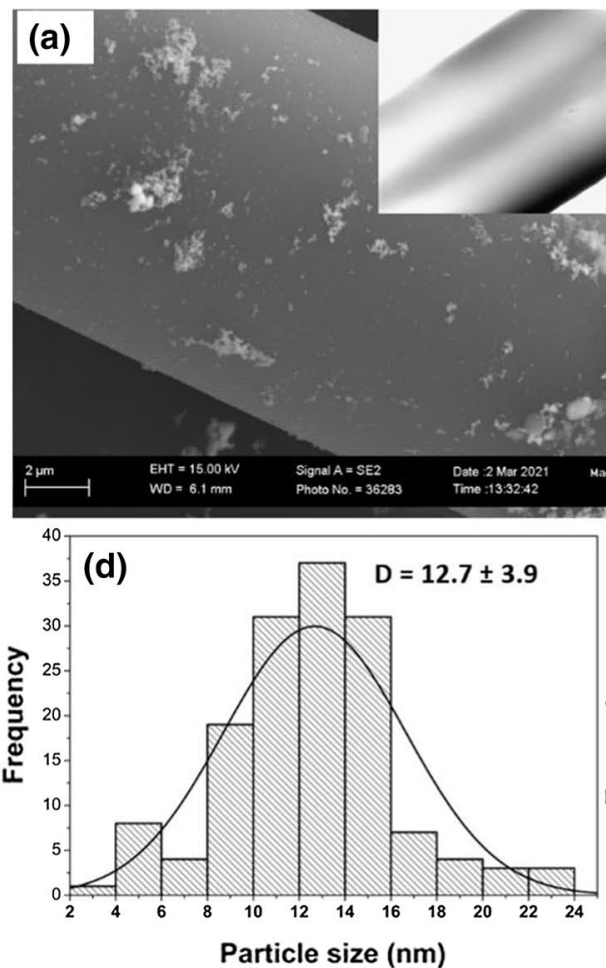

Particle size (nm)

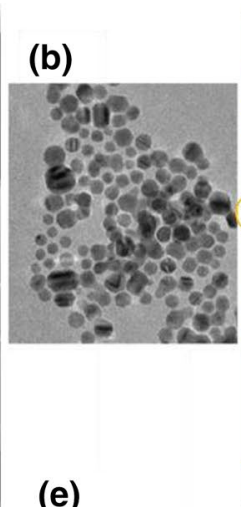

(e)
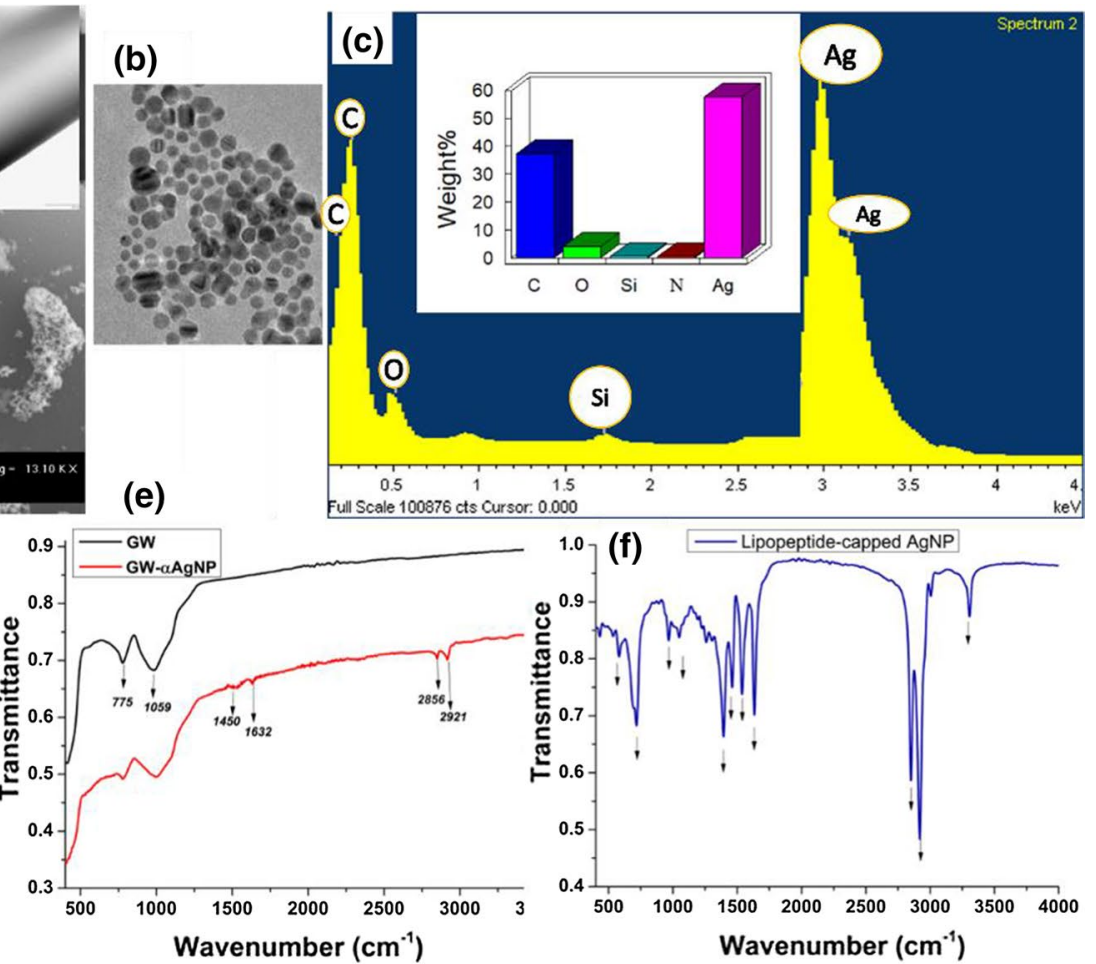

Fig. 1 Characterization of GW- $\alpha$ AgNP composite, a SEM image of GW- $\alpha \operatorname{AgNP}(2 \mu \mathrm{m}$ scale) (inset: TEM image of GW (200 nm scale)), b TEM image of oleylamine-capped AgNPs prior to doping experiment (50 nm scale), $\mathbf{c}$ EDS spectrum of GW- $\alpha \mathrm{AgNP}$ (inset: Relative

concentration ( $\mathrm{mg} / \mathrm{g}), C_{e}$ is the liquid phase equilibrium concentration $(\mathrm{mg} / \mathrm{L})$, and $K_{d}(\mathrm{~L} / \mathrm{g})$ is the sorption distribution coefficient (Ololade et al. 2018; Adeola \& Forbes 2019).

The isotherm regression parameters for Freundlich, Langmuir, Linear, and Sips model are presented in Table 1 and Fig. 2. The hysteresis index $(H)$ which is a measure of the abundance of constituent element obtained from EDS site mapping), d Particle size distribution of capped AgNPs with estimated diameter, $\mathbf{e}$ and $\mathbf{f}$ FTIR spectra of GW, GW- $\alpha \mathrm{AgNP}$ and oleylamine-capped AgNP

irreversibility of the sorption process was calculated for doped graphene wool and pristine graphene wool (Table 1). Isotherm data for $\mathrm{GW}-\alpha \mathrm{AgNP}$ adsorption of $\mathrm{BaP}$ was best described by a multilayer adsorption mechanism predicted by the Freundlich model with least ERRSQ $<0.79$, while $\mathrm{BaP}$ adsorption onto GW was best fitted to the Sips model
Table 1 Sorption-desorption parameters for adsorption of $\mathrm{BaP}$ onto GW- $\alpha \mathrm{AgNP}$ and $\mathrm{GW}$ (desorption hysteresis index (H) derived from Freundlich isotherm model)

\begin{tabular}{|c|c|c|c|c|c|c|}
\hline \multirow[t]{2}{*}{ Sorption models } & \multicolumn{3}{|c|}{ Adsorption parameters } & \multicolumn{3}{|c|}{ Desorption parameters } \\
\hline & & GW- $\alpha$ AgNP & GW & & GW- $\alpha \mathrm{AgNP}$ & GW \\
\hline & $K_{f(a d s)}$ & $1.12 \mathrm{e} 3$ & $0.60 \mathrm{e} 2$ & $K_{f(d e s)}$ & $0.55 \mathrm{e} 2$ & $0.21 \mathrm{e} 2$ \\
\hline \multirow[t]{2}{*}{ Freundlich } & $N_{(a d s)}$ & 3.13 & 0.1 & $N_{(d e s)}$ & 0.1 & 0.01 \\
\hline & SSE & 0.78 & 2.50 & ${ }^{*} H$-index & 31.3 & 10.0 \\
\hline \multirow[t]{3}{*}{ Langmuir } & $q_{\max }(\mu g / g)$ & $13.67 \mathrm{e} 3$ & $0.59 \mathrm{e} 2$ & & & \\
\hline & $K_{L}(L / \mu g)$ & $2.01 \mathrm{e}-4$ & $6.67 \mathrm{e} 4$ & & & \\
\hline & $S S E$ & 2.03 & 1.88 & & & \\
\hline \multirow[t]{2}{*}{ Linear } & $K_{d}$ & 2.75 & 0.93 & & & \\
\hline & SSE & 1.58 & 2.45 & & & \\
\hline \multirow[t]{4}{*}{ Sips } & $K_{s}$ & 3.36 & 2.38 & & & \\
\hline & $q_{m}(\mu g / g)$ & 97.62 & 59.76 & & & \\
\hline & $m_{s}$ & 9.68 & 6.05 & & & \\
\hline & $S S E$ & 2.03 & 1.87 & & & \\
\hline
\end{tabular}

${ }^{*} H$ : Sorption-desorption hysteresis index, $H=N_{a d s} / N_{d e s}$ 
(a)

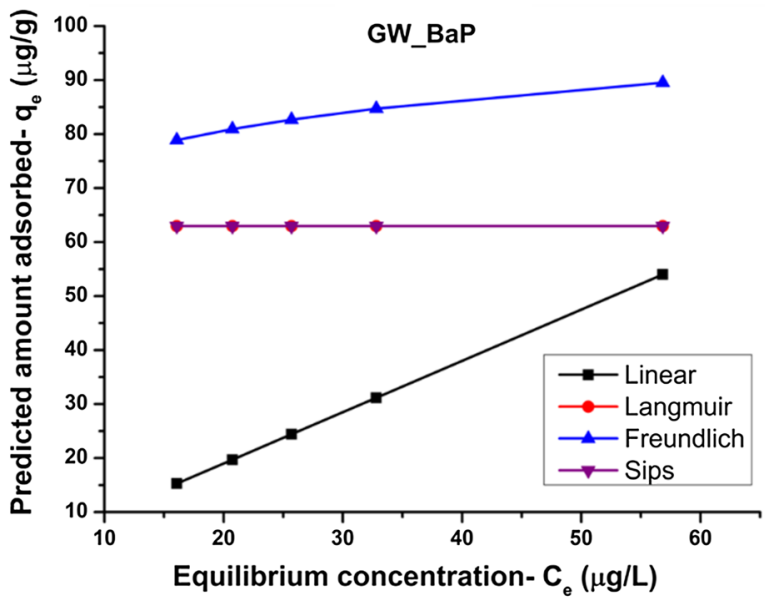

(b)

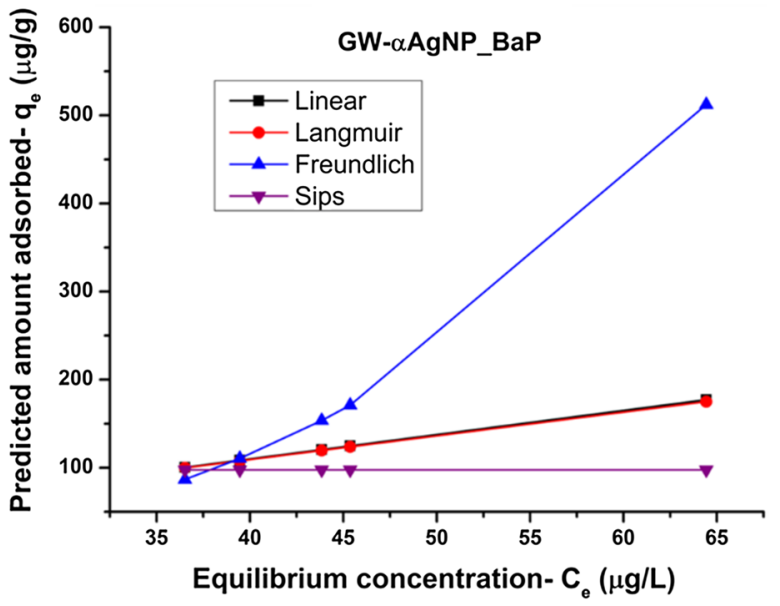

Fig. 2 Adsorption isotherm model plots for the interaction between sorbate and sorbents a GW and BaP b doped GW- $\alpha \mathrm{AgNP}$ and BaP. (Experimental conditions: $\mathrm{C}_{\mathrm{o}}=100-500 \mu \mathrm{g} / \mathrm{L}$; dosage $=5 \mathrm{mg}$ per $5 \mathrm{~mL}$, mixing rate $=200 \mathrm{rpm}, \mathrm{T}=25 \pm 1{ }^{\circ} \mathrm{C}$, contact time: $24 \mathrm{~h}$ )

(Langmuir-Freundlich hybrid) with ERRSQ $<1.88$, respectively (Table 1). These findings are consistent with previous results obtained from the adsorption of phenanthrene and pyrene onto pristine graphene wool (Adeola \& Forbes 2019). The doping of graphene wool with hydrophobic AgNPs coated with organic functional moieties significantly increased the maximum adsorption capacity of GW- $\alpha \mathrm{AgNP}$ over GW based on the $q_{\max } \& q_{m}$ predicted by Langmuir and Sips models, respectively (Table 1). BaP is a hydrophobic PAH with a high octanol-water partition coefficient $\log K_{o w}$ of 6.13 (Adeola \& Forbes 2020), and several reports suggest a strong affinity between PAHs and hydrophobic surfaces of adsorbents (Khan et al. 2007; Lamichhane et al. 2016; Yakout \& Daifullah 2013; Yuan et al. 2018). $\pi-\pi$ interactions between the graphene wool composite and the aromatic structure of $\mathrm{BaP}$, due to the presence of delocalized electrons, also contributes to the adsorption process (Zhao et al. 2011; Zhang et al. 2013; Yang et al. 2015; Adeola \& Forbes 2019).

Furthermore, oleylamine and oleic acid used as capping agents as well as the linker between GW and AgNP are large hydrophobic organic molecules that may have improved the surface hydrophobicity of the composite. Thus, this may in turn enhance partitioning (mass transfer) of hydrophobic $\mathrm{BaP}$ onto the surface of the composite, leading to enhanced adsorption capacity $\left(K_{d}\right.$ and $q_{\max }$ ). The doping of graphene with oleylamine-capped AgNPs accounts for the comparatively high surface and adsorption heterogeneity $\left(N \& m_{s}\right)$ index (Table 1). It is evident that adsorption-desorption interactions between sorbate and sorbents displayed a significant degree of hysteresis, as calculated $H$-index values for both sorbates were greater than $1\left(N_{a d s}>>>N_{d e s}\right)$ (Table 1) (Ololade et al. 2018; Adeola \& Forbes 2021a). However, irreversible entrapment and/or slow rate of desorption of sorbed $\mathrm{BaP}$ was three-fold higher in $\mathrm{GW}-\alpha \mathrm{AgNP}$ than pristine GW, further confirming higher binding strength with $\mathrm{BaP}$. Pore deformation and alteration of the surface structure of sorbents via build-up in unrelaxed pore volume also cause hysteretic behavior in sorption processes (Nguyen et al. 2004; Cornelissen et al. 2005). Therefore, the high hysteretic behavior of GW- $\alpha$ AgNP, which exemplifies better retention of $\mathrm{BaP}$ against recontamination of treated water, maybe due to entrapment of solutes by the collapse of the GW- $\alpha$ AgNP composite structure due to the adsorption process conditions and agitation.

\section{Comparison of adsorbents reported for benzo(a)pyrene removal}

Table 2 reveals that graphene wool $(\mathrm{GW})$ and doped graphene wool (GW- $\alpha$ AgNP) competes favorably with other adsorbents reported in the literature for the removal of benzo(a)pyrene from aqueous solutions, with efficiency '94\%. The maximum adsorption capacity deduced from the Langmuir isotherm model $\left(q_{\max }\right)$ for GW is lower than some of the adsorbents, however, the adsorption capacity of $\mathrm{GW}-\alpha \mathrm{AgNPs}$ is higher than activated carbon (AC), biochar and granular activated carbon (GAC) for BaP adsorption based on available literature. The higher adsorption capacity of GW- $\alpha$ AgNP may be due to surface modification associated with the doping experiment; creation of binding sites/ pores and enhanced hydrophobic sorbate-sorbent interactions. Oleylamine and oleic acid used as capping agents as well as the linker between GW and AgNP are large hydrophobic organic molecules that may have improved the surface hydrophobicity of the composite.

Several factors influence the choice of adsorbent for water treatment applications, these factors include efficiency, 
Table 2 Comparison of different materials used for removal of benzo(a)pyrene from aqueous solutions

\begin{tabular}{lclll}
\hline Adsorbent & Dosage (g/L) & $\begin{array}{l}\text { Removal effi- } \\
\text { ciency (\%) }\end{array}$ & $\begin{array}{l}\text { Adsorption } \\
\text { capacity (mg/g) }\end{array}$ & Reference \\
\hline Wood ash & 10.0 & $>99$ & - & $\begin{array}{l}\text { Pérez-Gregorio et al. (2010) } \\
\text { Amstaetter et al. (2012) }\end{array}$ \\
Activated carbon derived from coconut shells & 0.5 & 88 & - & Hassan et al. (2018) \\
Iron oxide nanoparticles (IONPs) & 0.13 & 99 & 0.029 & Minkina et al. (2021) \\
Granular activated carbon (GAC) & 50.0 & - & 2.176 & Minkina et al. (2021) \\
Biochar & 50.0 & - & 5.881 & Ilyas et al. (2021) \\
Activated carbon derived from plastic waste & 0.8 & 85 & 6.494 & This study \\
Graphene wool (GW) & 1.0 & 94.8 & 0.590 & This study \\
GW- $\alpha$ AgNPs & 1.0 & 98.7 & 13.670 & \\
\hline
\end{tabular}

non-toxicity, availability of material, flexibility, reusability, etc. (Adeola et al. 2021). However, the wool-like form and porosity of GW- $\alpha \mathrm{AgNP}$, in addition to the potential antibacterial activity (discussed in Sect. 3.6), are advantages to the use of GW- $\alpha \mathrm{AgNP}$ as a packing material for water treatment applications.

\section{Effect of initial pH on BaP adsorption}

The mineral, organic and biotic composition of surface waters depends on the source and geographic location, which in turn affects the water $\mathrm{pH}$ and influences the adsorption of chemical pollutants (Kulthanan et al. 2013). Solution $\mathrm{pH}$ affects the net charge of the adsorbent and adsorbate, and the alterations are more impactful in compounds and materials with protonated moieties $\left(-\mathrm{OH},-\mathrm{COOH},-\mathrm{NH}_{2}\right.$ group, etc.) because they tend to form deprotonated groups/ complexes under variable $\mathrm{pH}$ conditions (Ahmed \& Gasser 2012). In principle, at $\mathrm{pH}<$ point of zero charge (PZC), the surface of the adsorbent is positively charged and at $\mathrm{pH}>\mathrm{PZC}$, sorbents become negatively charged (Liikanen et al. 2006; Ololade et al. 2018). The results obtained in this study revealed that the optimum adsorption of $\mathrm{BaP}$ by GW- $\alpha$ AgNP occurred under basic $\mathrm{pH}$ conditions. This is in contrast to GW adsorption of PAHs that was slightly favored under acidic pH (Adeola \& Forbes 2019).

Figure 3 reveals that the adsorption is favored to the right side of the $\mathrm{pH}$ scale due to the nature of the oleylaminecapped AgNP-GW complex, the surface modification, and the abundance of hydroxide ions in basic $\mathrm{pH}$ that potentially facilitates hydrogen bonding as discussed in Sect. 3.2. Furthermore, excess hydroxide ions at $\mathrm{pH}>7$ could potentially lead to the formation of silver hydroxide, which is hydrophobic and thus enhances the more hydrophobic interactions with $\mathrm{BaP}$, which often governs the adsorption and partitioning of hydrophobic organic compounds (HOC) in water (Vasileva et al. 2009; Apul et al. 2013; Bai et al. 2017; Adeola \& Forbes 2020, 2021b).

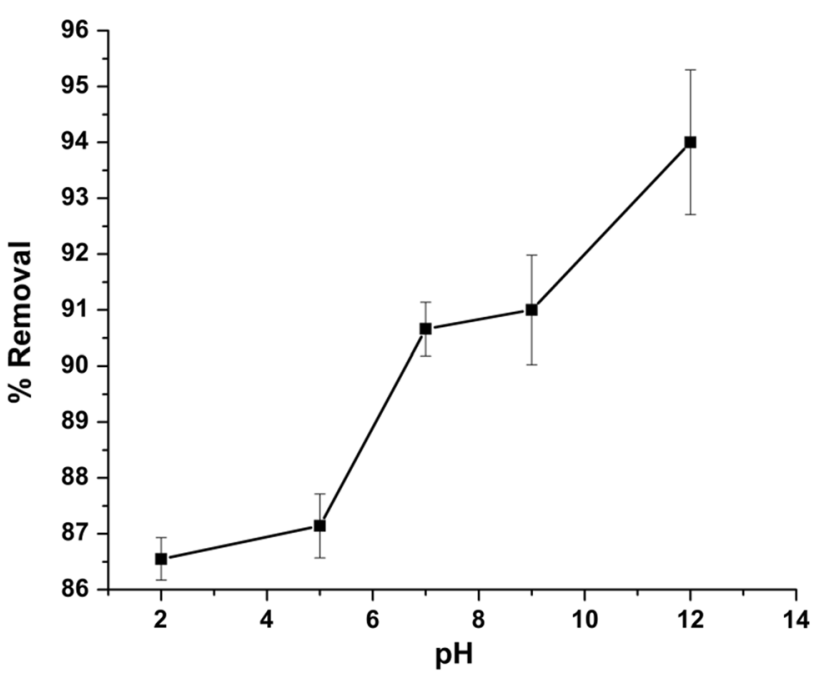

Fig. 3 Effect of $\mathrm{pH}$ on $\mathrm{BaP}$ adsorption onto GW- $\alpha \mathrm{AgNP}$ (Experimental conditions: $\mathrm{C}_{\mathrm{o}}=300 \mu \mathrm{g} / \mathrm{L}$; dosage $=5 \mathrm{mg}$ per $5 \mathrm{~mL}$, mixing rate $=200 \mathrm{rpm}, \mathrm{T}=25 \pm 1{ }^{\circ} \mathrm{C}$, contact time: $24 \mathrm{~h}$ ). Error bars \pm relative standard deviation (RSD), $\mathrm{n}=3$

\section{Influence of NOM on sorbent-sorbate interaction}

Natural organic matter (NOM) is a complex matrix of organic materials which are present in aquatic environments, including drinking water, due to the interconnectivity between the hydrologic cycle, biosphere, and geosphere within the ecosystem (Sillanpää et al. 2018). The composition of NOM is influenced by biogeochemical processes that have occurred within the environment (Myneni 2019). In this study, NOM was isolated from stream sediment collected from the University of Pretoria sports campus, South Africa (latitude E28 $8^{\circ} 14^{\prime} 46^{\prime \prime}$ and longitude S25 $5^{\circ} 45^{\prime} 10^{\prime \prime}$ ) using established procedures (Ran et al. 2007; Ololade et al. 2018; Adeola \& Forbes 2021a). The mineral phase was removed from bulk samples via treatment with $1 \mathrm{~N} \mathrm{HCl}$ for $45 \mathrm{~min}$ at ambient temperature, followed by three consecutive treatments with $1 \mathrm{~N} \mathrm{HCl}$ and $10 \% \mathrm{HNO}_{3}$ for $12 \mathrm{~h}$ 


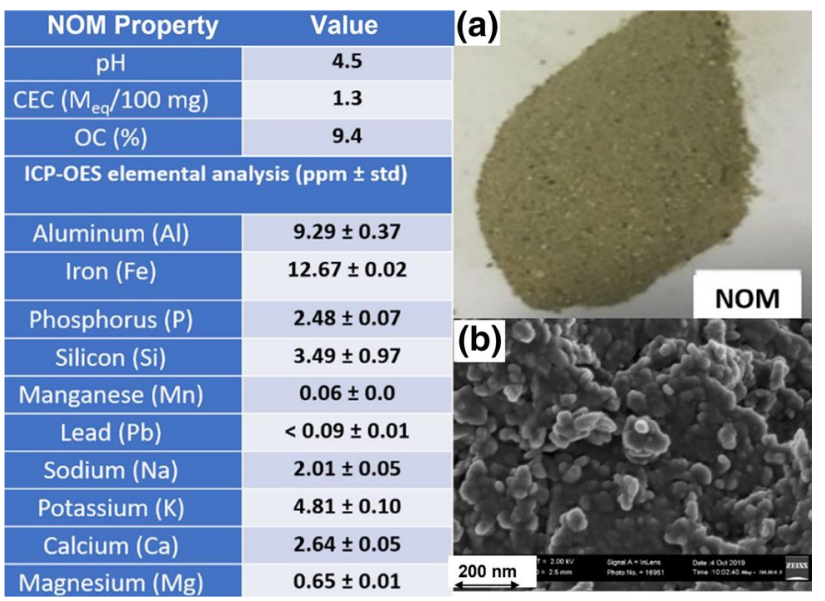

Fig. 4 Physicochemical properties and morphology of NOM isolate. Elemental composition was determined using ICP-OES. a Optical image and b SEM image of NOM (200 nm)

(Gelinas et al. 2001). The residue was washed each time with DI water, centrifuged at $6000 \mathrm{rpm}$ for $10 \mathrm{~min}$, decanted, and freeze-dried at $-4{ }^{\circ} \mathrm{C}$ for $24 \mathrm{~h}$ prior to use. Morphological and basic characterization of the NOM was carried out as presented in Fig. 4 (see Adeola and Forbes 2021b for more details). The NOM isolate had an irregular, spherical grain structure with heterogeneous and porous surface morphology (Fig. 4).

The effect of NOM on the adsorption of BaP by GW- $\alpha$ AgNP was evaluated using a preloading batch experiment (Adeola \& Forbes 2021a; Ersan et al. 2016). Figure 5 suggests that significant competitive interactions took place between the NOM, BaP molecules, and the adsorbent leading to the comparative decline in removal efficiency, Freundlich adsorption capacity $\left(K_{f}\right)$, partition coefficient $\left(K_{d}\right)$, and maximum adsorption capacity $\left(q_{\max }\right)$. NOM has been reported to cause fouling of membranes, and retention of hydrophobic compounds and metals in solution, thus limiting the efficiency of conventional water treatment plants (Mehta et al. 2017; Kurwadkar et al. 2019; Adeola \& Forbes 2021b). Essentially, NOM often alters the solution's chemistry such as $\mathrm{pH}$, ionic strength, and the presence of leachable trace and heavy metals (Fig. 4), providing a plausible explanation for the inhibitory role of NOM (Ersan et al. 2016; Lamichhane et al. 2016; Adeola \& Forbes 2021a).

\section{Effect of temperature and thermodynamic studies}

Several physicochemical and biological processes are influenced by temperature. Therefore, the role of temperature on the adsorption of $\mathrm{BaP}$ by pristine $\mathrm{GW}$ and doped $\mathrm{GW}-\alpha \mathrm{AgNP}$ was studied at 35,45 , and $55^{\circ} \mathrm{C}$, respectively. The adsorption data were fit to a linear and Sips isotherm models (Eq. 3 and 6), and it was observed that the maximum adsorption capacity $\left(q_{m}\right)$ significantly reduced for GW- $\alpha$ AgNP with an increase in temperature, while the reverse was observed for $\mathrm{GW}$ (Table 3, Fig. 6). The free energy change $\left(\Delta \mathrm{G}^{\circ}\right)$, enthalpy $\left(\Delta \mathrm{H}^{\circ}\right)$ and entropy $\left(\Delta \mathrm{S}^{\circ}\right)$ were calculated using the Van't Hoff plot and equations
Fig. 5 Influence of NOM on the removal efficiency and adsorption capacity of benzo(a) pyrene by GW- $\alpha$ AgNP. (Experimental conditions: $\mathrm{C}_{\mathrm{o}(\mathrm{BaP})}=100-500 \mu \mathrm{g} / \mathrm{L}$; sorbent dosage $=1 \mathrm{~g} / \mathrm{L}$, NOM dosage $=1 \mathrm{~g} / \mathrm{L}$, mixing rate $=200 \mathrm{rpm}, \mathrm{T}=25 \pm 1{ }^{\circ} \mathrm{C}$, contact time: $24 \mathrm{~h}$ )
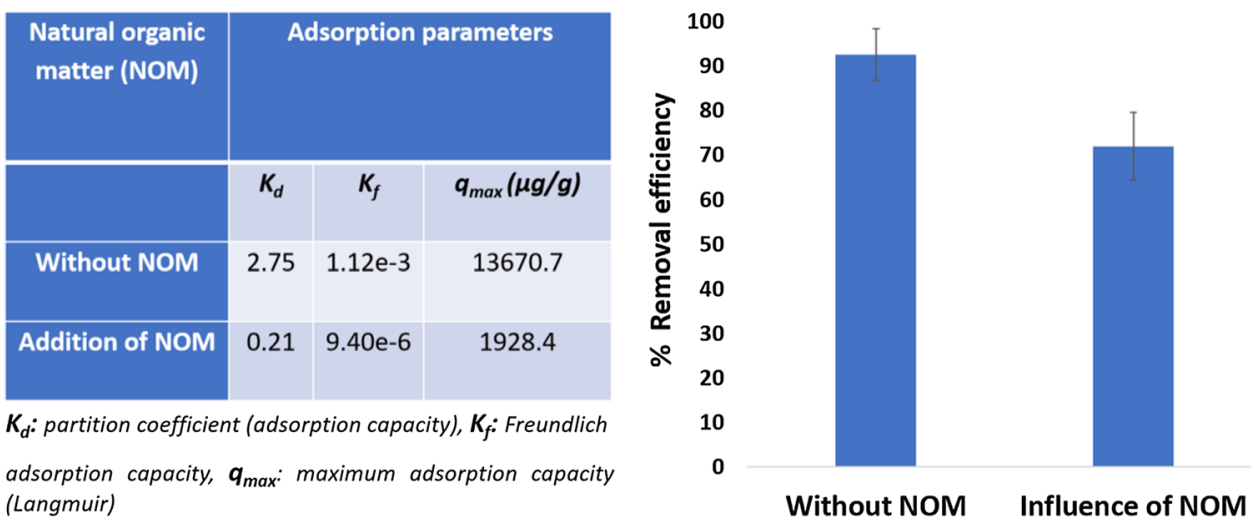

Table 3 Thermodynamic parameters for adsorption of $\mathrm{BaP}$ onto graphene wool and doped graphene wool

\begin{tabular}{|c|c|c|c|c|c|c|c|c|}
\hline \multirow[t]{2}{*}{ Temp. (K) } & \multicolumn{4}{|l|}{ GW } & \multicolumn{4}{|l|}{ GW- $\alpha \mathrm{AgNP}$} \\
\hline & $\Delta \mathrm{G}^{\circ}(\mathrm{J} / \mathrm{mol})$ & $\Delta \mathrm{H}^{\circ}(\mathrm{kJ} / \mathrm{mol})$ & $\Delta \mathrm{S}^{\circ}(\mathrm{kJ} / \mathrm{mol} . \mathrm{K})$ & $* q_{m}(\mu \mathrm{g} / \mathrm{g})$ & $\Delta \mathrm{G}^{\circ}(\mathrm{J} / \mathrm{mol})$ & $\Delta \mathrm{H}^{\circ}(\mathrm{kJ} / \mathrm{mol})$ & $\Delta \mathrm{S}^{\circ}(\mathrm{kJ} / \mathrm{mol} . \mathrm{K})$ & $* q_{m}(\mu \mathrm{g} / \mathrm{g})$ \\
\hline 298 & 50.02 & & & 59.75 & -2507.55 & & & 97.62 \\
\hline 308 & -2560.71 & 94.42 & 0.32 & 63.09 & -1636.57 & -24.04 & -0.07 & 84.14 \\
\hline 318 & -6296.06 & & & 66.36 & -1065.57 & & & 76.88 \\
\hline
\end{tabular}

${ }^{*} q_{m}:$ maximum adsorption capacity derived from Sips model 


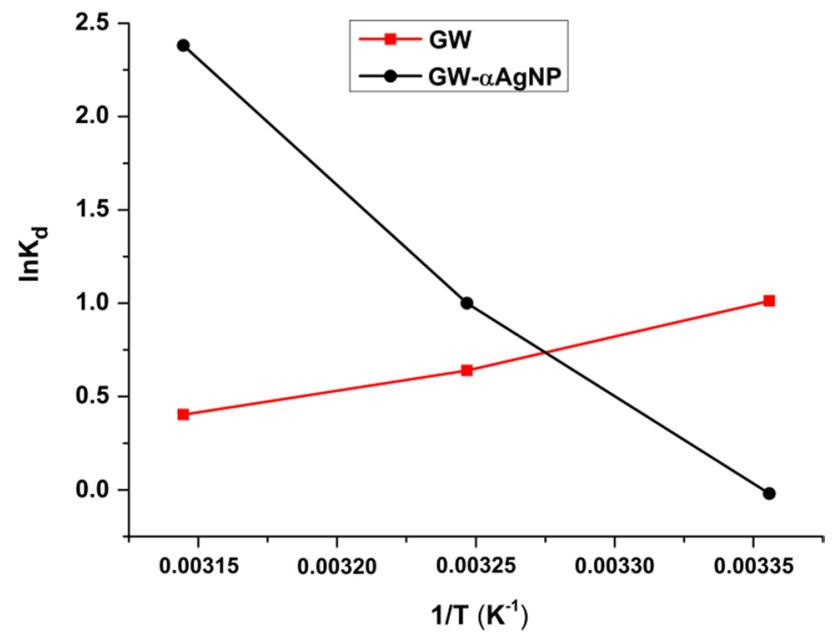

Fig. 6 Van't Hoff equation for $\mathrm{BaP}$ adsorption onto $\mathrm{GW}$ and GW- $\alpha$ AgNP from aqueous solution

(eqs. 8 and 9) (Fig. 6), in order to elucidate the thermodynamic nature of adsorption of $\mathrm{BaP}$ as a function of temperature (Yakout \& Daifullah 2013; Adeola \& Forbes 2019).

$\ln K_{d}=\frac{\Delta S^{\circ}}{R}-\frac{\Delta H^{\circ}}{R T}$

$\Delta G^{\circ}=\Delta H^{\circ}-T \Delta S^{\circ}$

where $\Delta G$ is the change in the Gibbs free energy ( $\mathrm{cal} / \mathrm{mol})$; $\Delta H$ is the change in enthalpy ( $\mathrm{cal} / \mathrm{mol})$, and $\Delta S$ is the change in entropy $(\mathrm{kJ} / \mathrm{mol} . \mathrm{K}), \mathrm{R}=$ gas constant $(8.314 \mathrm{~J} / \mathrm{mol} . \mathrm{K})$, $\mathrm{T}=$ thermodynamic temperature $(\mathrm{K})$ and $K_{d}$ is adsorption capacity determined from the linear isotherm model.
Table 3 revealed positive values of adsorption enthalpy $\left(\Delta H^{\circ}\right)$ and entropy $\left(\Delta S^{\circ}\right)$, and a negative value of $\Delta G$ for GW-BaP interaction, which indicates a spontaneous endothermic process as the temperature increased (Ahmed \& Gasser 2012). This result is in agreement with a previous study on the adsorption of phenanthrene and pyrene by GW (Adeola \& Forbes 2019). In contrast, GW- $\alpha$ AgNP-BaP interaction is a spontaneous exothermic process (negative $\Delta H^{\circ}$ and $\Delta G$ ), with a reduction in system chaos (negative $\Delta S^{\circ}$ ) and adsorption capacity as the temperature is increased. While GW is more efficient at elevated temperatures, doping GW with oleylamine-capped AgNPs improved the adsorption capacity and ensured optimum removal efficiency at ambient temperature, which is better in terms of energy economics and industrial application.

\section{Antibacterial activity of GW-aAgNP}

Silver nanoparticles and composites have attracted scientific attention due to the continuous upsurge of drug-resistant bacteria (Bezza et al. 2020; Cobos et al. 2020). Bacterial strains are classified as Gram-positive $(\mathrm{G}+\mathrm{ve})$ or Gramnegative (G-ve) based on film assemblage with layers of peptidoglycan (PG) (Proft and Baker 2009). G-ve microbes have a thin PG (1-5 nm) between the cytoplasmic film and external layer, while $\mathrm{G}+$ ve microbes have a thicker PG layer $(\sim 30 \mathrm{~nm})$ without an external film (Kim et al. 2007). The mechanism of action of silver-containing materials is described in Fig. 7. Silver damages the cytoplasmic membrane of microbes, creates oxidative stress with the cells, damages DNA, denatures cell proteins and has a lethal effect on microorganisms, including drug-resistant bacteria (Ahmad et al. 2020).
Fig. 7 A plausible mechanism for the antimicrobial action of silver nanoparticles. (Reproduced with permission from Ahmad et al. Copyright 2020, Elsevier)

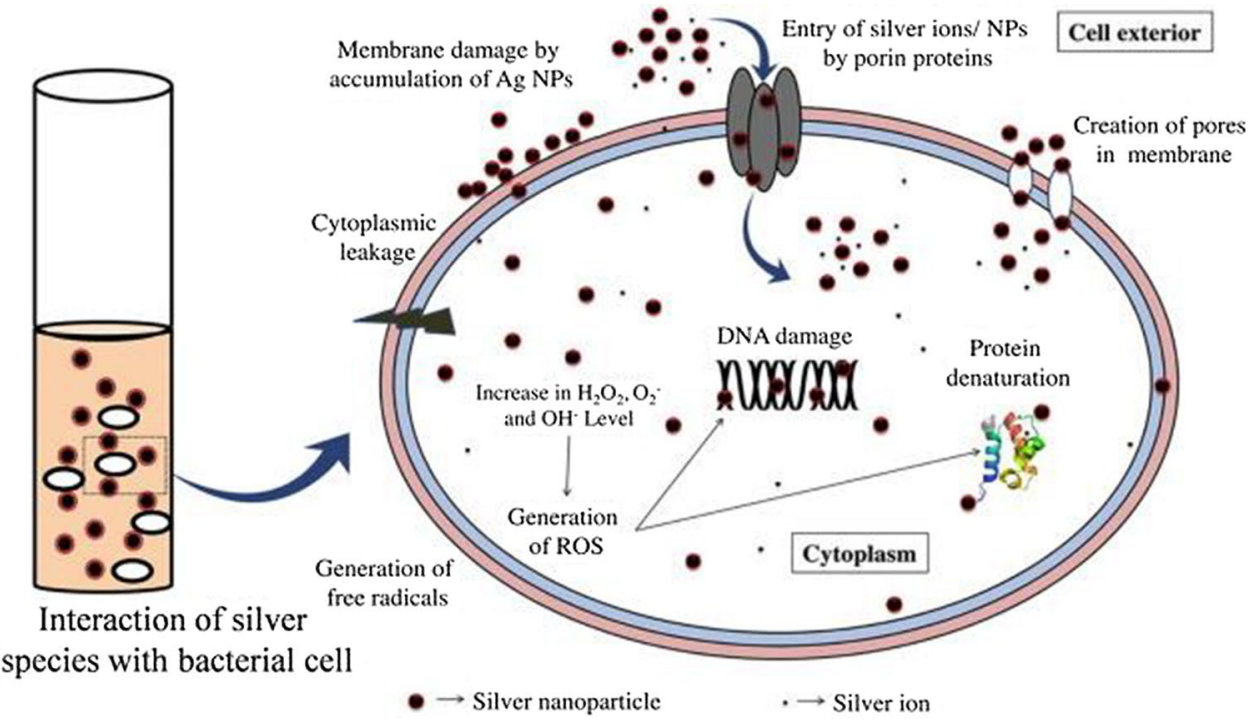

$$
\text { - } \rightarrow \text { Silver nanoparticle } \quad \cdot \rightarrow \text { Silver ion }
$$


Several studies have established the antibacterial action of AgNPs and composites, with different minimum inhibitory concentrations against some drug-resistant microbes (Table 4). The minimum inhibitory concentration (MIC) is regarded as the lowest concentration of an antimicrobial agent that inhibits the growth of microbes, recorded in $\mathrm{mg} / \mathrm{L}$ or $\mu \mathrm{g} / \mathrm{mL}$ (Cobos et al. 2020). The literature suggests that AgNPs and bimetallic nanocomposites (such as $\mathrm{Au}-\mathrm{Ag}$, $\mathrm{Fe}-\mathrm{Ag}$ ) are more effective against microorganisms based on MIC values; however, the potential adverse effects of AgNPs on human health have been a major concern, hence research into stabilizing AgNPs using capping agents and entrapment within a bulky substrate to limit its release potential/ contamination in aqueous media has gained vast attention (Liu et al. 2011; Loan Khanh et al. 2019; Bezza et al. 2020).

The antibacterial activity of GW- $\alpha$ AgNPs and pristine AgNPs was tested against the Gram-negative Pseudomonas aeruginosa CB1 and Gram-positive Bacillus subtilis CN2 strains by the standard micro-dilution method. Earlier reports suggest that $P$. aeruginosa and $B$. subtilis strains are capable of adaptive resistance to antibiotics such as penicillin and tetracycline (Araya et al. 2019; Pang et al. 2019). Figure 8 reveals a dose-dependent reduction in the concentration of Gram-negative Pseudomonas aeruginosa CB1 and Gram-positive Bacillus subtilis CN2 strains after $24 \mathrm{~h}$ incubation period as a decrease in turbidity was recorded

Table 4 A brief summary of silver-containing composites and microorganisms inhibited along with their minimum inhibitory concentrations (MIC) as reported in the literature $(\mathrm{mg} / \mathrm{L})$

\begin{tabular}{|c|c|c|c|}
\hline Composite & Microbes & $\begin{array}{l}\text { Minimum inhibitory } \\
\text { concentration }(\mathrm{mg} / \mathrm{L})\end{array}$ & References \\
\hline $\begin{array}{l}\text { AgNPs/starch/sodium alginate/lemon- } \\
\text { grass oil }\end{array}$ & Escherichia coli & Not reported & Maizura et al. (2007) \\
\hline Sodium Alginate/AgNPs & $\begin{array}{l}{ }^{a} \text { Staphylococcus aureus, } \\
{ }^{b} \text { Escherichia coli }\end{array}$ & ${ }^{\mathrm{a}} 80,{ }^{\mathrm{b}} 40$ & Mohammed Fayaz et al. (2009) \\
\hline Silver nanocomposites & $\begin{array}{l}{ }^{a} \text { Staphylococcus aureus, } \\
{ }^{b} \text { Escherichia coli, } \\
{ }^{c} \text { Candida albicans, } \\
{ }^{d} \text { Aspergillus niger }\end{array}$ & ${ }^{\mathrm{a}} 250,{ }^{\mathrm{b}} 62.5,{ }^{\mathrm{c}} 125,{ }^{\mathrm{d}} 2000$ & Egger et al. (2009) \\
\hline $\begin{array}{l}\text { Bimetallic Au@Ag core-shell nanopar- } \\
\text { ticles }\end{array}$ & $\begin{array}{l}{ }^{a} \text { Escherichia coli, } \\
{ }^{b} \text { Pseudomonas aeruginosa, } \\
{ }^{c} \text { Enterococcus faecalis }\end{array}$ & ${ }^{\mathrm{a}} 1.56,{ }^{\mathrm{b}} 1.88,{ }^{\mathrm{c}} 2.5$ & Banerjee et al. (2011) \\
\hline AgNP-Bovin serum albumin (BSA) & $\begin{array}{l}\text { Staphylococcus aureus, } \\
\text { Escherichia coli, } \\
\text { Enterococcus faecalis }\end{array}$ & 469.2 & Espinosa-Cristóbal et al. (2015) \\
\hline $\begin{array}{l}\text { Polycaprolactone-silver composites } \\
\text { (PCL-AgNPs) }\end{array}$ & $\begin{array}{l}\text { Escherichia coli, Staphylococcus aureus, } \\
\text { Pseudomonas aeruginosa }\end{array}$ & 12.5 & Pazos-Ortiz et al. (2017) \\
\hline $\begin{array}{l}\text { Ag-microfibrillated cellulose biocom- } \\
\text { posite }\end{array}$ & $\begin{array}{l}{ }^{a} \text { Escherichia coli, }{ }^{\mathrm{b}} \text { Staphylococcus } \\
\text { aureus, }{ }^{\mathrm{c}} \text { Pseudomonas aeruginosa }\end{array}$ & ${ }^{\mathrm{a}} 125,{ }^{\mathrm{b}} 1500,{ }^{\mathrm{c}} 125$ & Garza-Cervantes et al. (2020) \\
\hline Chitosan-AgNP & Staphylococcus aureus & 32.98 & Quintero-Quiroz et al. (2020) \\
\hline Ag-Fe bimetallic nanoparticles & $\begin{array}{l}{ }^{a} \text { Staphylococcus aureus, } \\
{ }^{b} \text { Escherichia coli, } \\
{ }^{c} \text { Candida albicans, } \\
{ }^{\mathrm{d}} \text { Pseudomonas aeruginosa }\end{array}$ & a,b $125,{ }^{\mathrm{c}} 62.5,{ }^{\mathrm{d}} 31.23$ & Padilla-Cruz et al. (2021) \\
\hline Graphene oxide-AgNP & $\begin{array}{l}{ }^{a} \text { Staphylococcus aureus, } \\
{ }^{b} \text { Escherichia coli, } \\
{ }^{c} \text { Candida albicans, } \\
{ }^{\mathrm{d}} \text { Pseudomonas aeruginosa }\end{array}$ & $\begin{array}{l}\text { Not reported } \\
{ }^{\mathrm{b}, \mathrm{d}} 64,{ }^{\mathrm{a}, \mathrm{c}} 32\end{array}$ & $\begin{array}{l}\text { Jaworski et al. (2018) } \\
\text { Cobos et al. (2020) }\end{array}$ \\
\hline $\mathrm{AgNP}$ & $\begin{array}{l}{ }^{a} \text { Staphylococcus aureus, } \\
{ }^{b} \text { Escherichia coli, } \\
{ }^{c} \text { Candida albicans, } \\
{ }^{\mathrm{d}} \text { Pseudomonas aeruginosa }\end{array}$ & $\begin{array}{l}<8.0 \\
10-12 \\
{ }^{a b c} 125,{ }^{d} 62.5\end{array}$ & $\begin{array}{l}\text { Gurunathan (2019); Loo et al. } \\
\text { (2018) } \\
\text { Dong et al. (2019); Vazquez- } \\
\text { Muñoz et al. (2019) } \\
\text { Padilla-Cruz et al. (2021) }\end{array}$ \\
\hline Gelatin-stabilized AgNPs and curcumin & $\begin{array}{l}\text { Staphylococcus aureus, Pseudomonas } \\
\text { aeruginosa }\end{array}$ & 125 & Loan Khanh et al. (2019) \\
\hline Lipopetide-capped AgNP & $\begin{array}{l}\text { Pseudomonas aeruginosa, } \\
\text { Bacillus subtillis }\end{array}$ & 15.63 & Bezza et al. (2020) \\
\hline $\begin{array}{l}\text { Graphene wool doped with oleylamine- } \\
\text { capped AgNPs }\end{array}$ & $\begin{array}{l}\text { Pseudomonas aeruginosa, } \\
\text { Bacillus subtillis }\end{array}$ & 1000 & This study \\
\hline
\end{tabular}




\section{(a) Effect of graphene wool doped with silver nanoparticle}

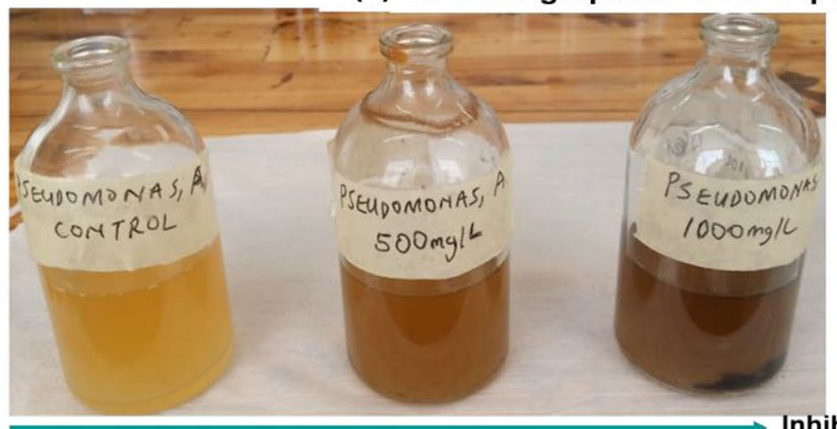

Decrease in turbidity (OD-600nm)- Pseudomonas aeruginosa

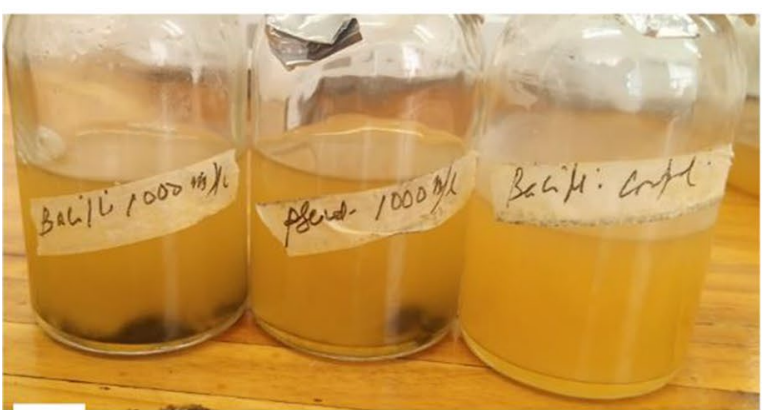

(b) Graphene wool without silver (1000 mg/L)

Fig. 8 Visible antibacterial activity of composites a 500 and $1000 \mathrm{mg} / \mathrm{L}$ of GW- $\alpha \mathrm{AgNP}$ in $100 \mathrm{~mL}$ TSB nutrient medium inoculated with $P$. aeruginosa (left) and B. subtilis (right) b $1000 \mathrm{mg} / \mathrm{L}$ of $\mathrm{GW}$ in $100 \mathrm{~mL}$ TSB nutrient medium inoculated with $P$. aeruginosa and $B$. subtilis c Variation in concentration of respective bacteria

spectrophotometrically at an optical density of $600 \mathrm{~nm}$. The decline in turbidity is a function of bacteriostatic/bactericidal activity of the composite, relative to control experiments. The reduction is most significant at $1000 \mathrm{mg} / \mathrm{L}$ $(\mathrm{GW}-\alpha \mathrm{AgNP})$ and was more visible in doped GW than pristine GW. Factors such as particle size, stabilizing agent, composition of culture media and bacteria type, inoculum size, and leachability of silver ions from the composite, play a critical role in determining the MIC values. Optical density measurement is the most common technique for determining bacteria concentration and efficacy of antibacterial agents (McBirney et al. 2016; Huang et al. 2017). The agar disk diffusion test is another method often used for nanoparticles that are dispersible in water to form a uniform solution, however, due to the macroscopic and fibrous nature of GW, it was impossible to obtain a uniform dispersion of the material in the solution. When such experiments were attempted, the release and mobility of silver ions from the macrostructure through the semi-solid agar were significantly limited, thus constricting the inhibition zone to the site of deposition on the plate (Fig. 9), a similar finding was reported for large-sized AgNPs (Xiu et al. 2012; Bezza et al. 2020). However, the texture, fibrous nature, antibacterial and

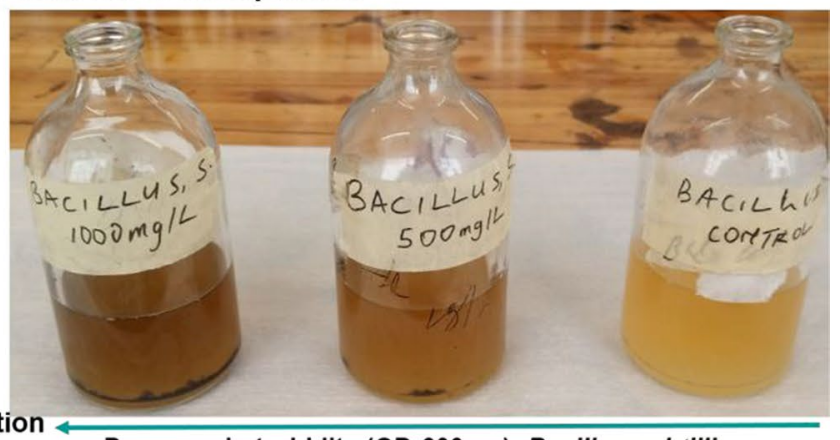

Decrease in turbidity (OD-600nm)- Bacillus subtillis

(c)

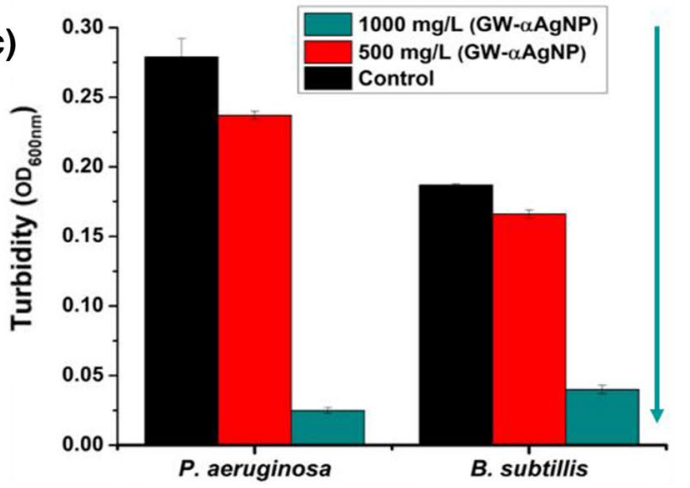

determined spectrophotometrically at an optical density of $600 \mathrm{~nm}$ $\left(\mathrm{OD}_{600 \mathrm{~nm}}\right), \mathrm{n}=2$. (100 mL TSB nutrient medium inoculated with $P$. aeruginosa and B. subtilis without $\mathrm{GW}$ or $\mathrm{GW}-\alpha \mathrm{AgNP}$ were included as controls)

adsorptive properties of GW- $\alpha$ AgNP suggest that the material may be suitable for the fabrication of adsorbent layer(s) in water filtration or purification devices.

\section{Conclusion}

Facile synthesis of GW doped with oleylamine-capped AgNPs was achieved in this study. The effect of concentration, $\mathrm{pH}$, and temperature on the adsorption of benzo(a) pyrene, a human carcinogen, was evaluated using the doped graphene wool. Isotherm data suggest that GW- $\alpha$ AgNP-BaP interaction is a spontaneous exothermic process (negative $\Delta H^{\circ}$ and $\Delta G$ ), characterized by a decline in system chaos (negative $\Delta S^{\circ}$ ) and adsorption capacity as temperature increases. This study suggests that the adsorption capacity of GW improved and will be more efficient at ambient temperature ( $\Delta G$ and $q_{\max }$ ), when doped with AgNPs as a result of improved surface hydrophobicity and heterogeneity, leading to the creation of more binding sites for $\mathrm{BaP}$ to adhere to. Results revealed a high degree of desorption hysteresis and irreversible sorption, suggesting a strong binding strength between the doped GW and pollutant, thus limiting

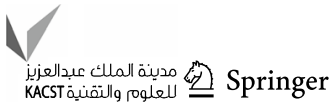


Fig. 9 Agar disk diffusion test a Before incubation- $100 \mathrm{mg}$ of $\mathrm{GW}-\alpha \mathrm{AgNP}$ was placed on agar disk with growth medium and Bacillus subtilis culture spread over uniformly, b After $24 \mathrm{~h}$ incubation- visible growth of the bacteria around GW- $\alpha$ AgNP with inhibition zone limited to the site of deposition

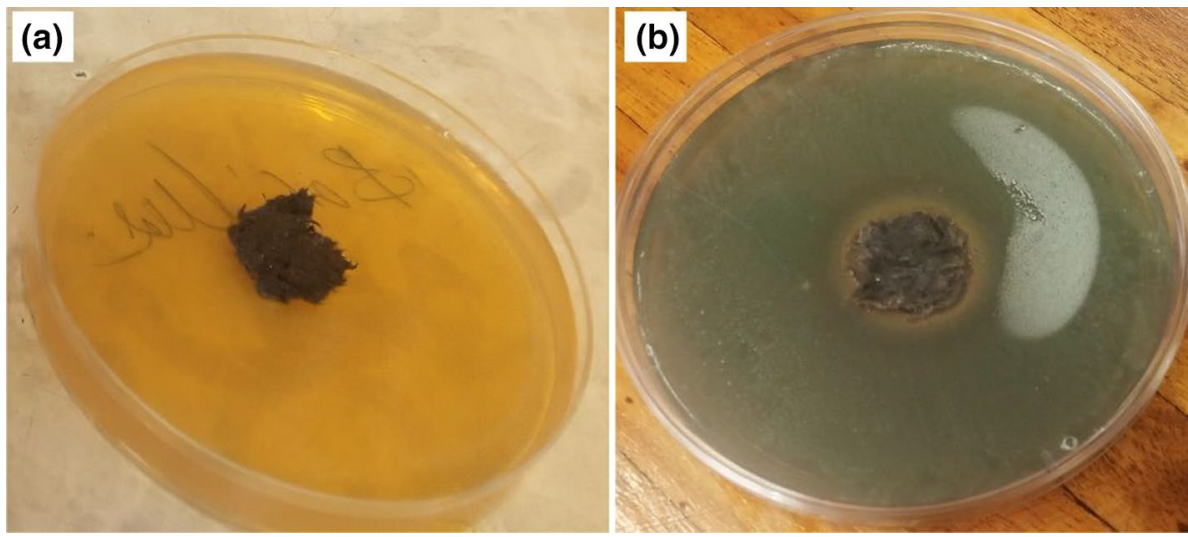

the ease of recontamination. Results also show that the presence of NOM in the aqueous matrix is undesirable for the application of the synthesized adsorbent due to competitive adsorption. Several studies have established the cytoplasmic toxicity and antimicrobial properties of silver-containing nanomaterials and in this study, preliminary results also revealed that there was a dose-dependent reduction in the concentration of Gram-negative Pseudomonas aeruginosa CB1 and Gram-positive Bacillus subtilis CN2 strains tested in the presence of GW- $\alpha \mathrm{AgNP}$.

Furthermore, unlike most composites that are generated in the form of flakes or powder, GW- $\alpha$ AgNP provides a wool-like form that may be more suitable as a packing material for filters and other water polishing tools due to its lightweight and porous nature. The synthesis of graphene wool is facile and eco-friendly without extensive use of chemicals. Therefore, under appropriate operating conditions, the graphene-based composite can potentially be utilized as a water polishing tool for the removal of emerging organic chemical pollutants. With further studies and suitable fabrication, this hybrid material has the potential to serve as a smart solution to chemical and microbial pollution in water.

Acknowledgements Authors acknowledge the assistance provided by Dr F. A. Bezza during the antibacterial testing of the composite, the University of Pretoria Commonwealth Doctoral Scholarship funding (AA) and the Rand Water Professorial Chair program (PF and EC) for providing funding for the research.

Funding This study is supported by University of Pretoria Commonwealth Doctoral Scholarship funding (AA) and the Rand Water Professorial Chair program (PF and EC).

\section{Declarations}

Conflict of interest The authors declare that there is no conflict of interest.

Ethical approval This article does not contain any studies with human participants or animals performed by any of the authors.
Open Access This article is licensed under a Creative Commons Attribution 4.0 International License, which permits use, sharing, adaptation, distribution and reproduction in any medium or format, as long as you give appropriate credit to the original author(s) and the source, provide a link to the Creative Commons licence, and indicate if changes were made. The images or other third party material in this article are included in the article's Creative Commons licence, unless indicated otherwise in a credit line to the material. If material is not included in the article's Creative Commons licence and your intended use is not permitted by statutory regulation or exceeds the permitted use, you will need to obtain permission directly from the copyright holder. To view a copy of this licence, visit http://creativecommons.org/licenses/by/4.0/.

\section{References}

Adeniji AO, Okoh OO, Okoh AI (2019) Levels of Polycyclic aromatic hydrocarbons in the water and sediment of buffalo river estuary, south africa and their health risk assessment. Arch Environ Contam Toxicol 76(4):657-669

Adeola AO, Forbes PBC (2019) Optimization of the sorption of selected polycyclic aromatic hydrocarbons by regenerable graphene wool. Water Sci Technol 80:1931-1943

Adeola AO, Forbes PBC (2020) Assessment of reusable graphene wool adsorbent for the simultaneous removal of selected 2-6 ringed polycyclic aromatic hydrocarbons from aqueous solution. Environ Technol. https://doi.org/10.1080/09593330.2020. 1824024

Adeola AO, Forbes PBC (2021a) Influence of natural organic matter fractions on PAH sorption by stream sediments and a synthetic graphene wool adsorbent. Environ Technol Innov 21:101202

Adeola AO, Forbes PBC (2021b) Advances in water treatment technologies for removal of polycyclic aromatic hydrocarbons: existing concepts, emerging trends, and future prospects. Water Environ Res 93:343-395

Ahmad HB, Yasmin GE, Arain SA, Bhatti IA, Hussain M (2015) Synthesis of some novel adsorbents for antimicrobial activity and removal of arsenic from drinking water. Korean J Chem Eng 32:661-666

Ahmad SA, Sachi Das S, Khatoon A, Tahir Ansari M, Afzal M, Saquib Hasnain M, Kumar Nayak A (2020) Bactericidal activity of silver nanoparticles: a mechanistic review. Mater Sci Energy Technologies 3:756-769

Ahmed IM, Gasser MS (2012) Adsorption study of anionic reactive dye from aqueous solution to $\mathrm{Mg}-\mathrm{Fe}-\mathrm{CO}_{3}$ layered double hydroxide (LDH). Appl Surf Sci 259:650-656 
Amari A, Elboughdiri N, Ghernaout D, Lajimi RH, Alshahrani AM, Tahoon MA, Rebah FB (2021) Multifunctional crosslinked chitosan/nitrogen-doped graphene quantum dot for wastewater treatment. Ain Shams Eng J. https://doi.org/10.1016/j.asej.2021. 02.024

Amstaetter K, Eek E, Cornelissen G (2012) Sorption of PAHs and PCBs to activated carbon: coal versus biomass-based quality. Chemosphere 87:573-578

Anthony KJP, Murugan M, Gurunathan S (2014) Biosynthesis of silver nanoparticles from the culture supernatant of Bacillus marisflavi and their potential antibacterial activity. J Ind Eng Chem 20:1505-1510

Apul OG, Wang Q, Zhou Y, Karanfil T (2013) Adsorption of aromatic organic contaminants by graphene nanosheets: comparison with carbon nanotubes and activated carbon. Water Res 47:1648-1654

Araya G, Benites J, Reyes JS, Marcoleta AE, Valderrama JA, Lagos R, Monasterio O (2019) Inhibition of Escherichia coli and Bacillus subtilis FtsZ Polymerization and Bacillus subtilis Growth by Dihydroxynaphtyl Aryl Ketones. Front Microbiol 10:1225. https://doi.org/10.3389/fmicb.2019.01225

Bai H, Zhou J, Zhang H, Tang G (2017) Enhanced adsorbability and photocatalytic activity of $\mathrm{TiO}_{2}$-graphene composite for polycyclic aromatic hydrocarbons removal in aqueous phase. Colloids Surf, B 150:68-77

Banerjee M, Sharma S, Chattopadhyay A, Ghosh SS (2011) Enhanced antibacterial activity of bimetallic gold-silver core-shell nanoparticles at low silver concentration. Nanoscale 3:5120-5125

Bezza FA, Chirwa EMN (2016) Biosurfactant-enhanced bioremediation of aged polycyclic aromatic hydrocarbons (PAHs) in creosote contaminated soil. Chemosphere 144:635-644

Bezza FA, Tichapondwa SM, Chirwa EMN (2020) Synthesis of biosurfactant capped silver nanoparticles characterization and their potential application for bactericidal purposes. J Hazard Mater 393:122319

Bushra R, Shahadat M, Ahmad A, Nabi SA, Umar K, Oves M, Raeissi AS, Muneer M (2014) Synthesis, characterization, antimicrobial activity and applications of polyanilineTi(IV)arsenophosphate adsorbent for the analysis of organic and inorganic pollutants. J Hazard Mater 264:481-489

Çınar S, Gündüz G, Mavis B, Çolak U (2011) Synthesis of silver nanoparticles by Oleylamine-Oleic acid reduction and its use in making nanocable by coaxial electrospinning. J Nanosci Nanotechnol 11:3669-3679

Cobos M, De-La-Pinta I, Quindós G, Fernández MJ, Fernández MD (2020) Graphene oxide-silver nanoparticle nanohybrids: synthesis, characterization, and antimicrobial properties. Nanomaterials 10(2):376

Cornelissen G, Gustafsson Ö, Bucheli TD, Jonker MTO, Koelmans AA, van Noort PCM (2005) Extensive sorption of organic compounds to black carbon, coal, and kerogen in sediments and soils: mechanisms and consequences for distribution, bioaccumulation, and biodegradation. Environ Sci Technol 39:6881-6895

Dana E, Taha A, Afkar E (2018) Green synthesis of iron nanoparticles by acacia nilotica pods extract and its catalytic, adsorption, and antibacterial activities. Appl Sci 8:1922

Dong Y, Zhu H, Shen Y, Zhang W, Zhang L (2019) Antibacterial activity of silver nanoparticles of different particle size against Vibrio Natriegens. PLOS ONE, 14, e0222322

Egger S, Lehmann RP, Height MJ, Loessner MJ, Schuppler M (2009) Antimicrobial properties of a novel silver-silica nanocomposite material. Appl Environ Microbiol 75:2973

Eltugral N, Simsir H, Karagoz S (2016) Preparation of nano-silversupported activated carbon using different ligands. Res Chem Intermed 42:1663-1676
Ersan G, Kaya Y, Apul OG, Karanfil T (2016) Adsorption of organic contaminants by graphene nanosheets, carbon nanotubes and granular activated carbons under natural organic matter preloading conditions. Sci Total Environ 565:811-817

Espinosa-Cristóbal LF, Martínez-Castañón GA, Loyola-Rodríguez JP, Niño-Martínez N, Ruiz F, Zavala-Alonso NV, Lara RH, ReyesLópez SY (2015) Bovine serum albumin and chitosan coated silver nanoparticles and its antimicrobial activity against oral and nonoral bacteria. J Nanomater, 420853

Fayaz AM, Balaji K, Girilal M, Kalaichelvan PT, Venkatesan R (2009) Mycobased synthesis of silver nanoparticles and their incorporation into sodium alginate films for vegetable and fruit preservation. J Agric Food Chem 57:6246-6252

Garza-Cervantes JA, Mendiola-Garza G, de Melo EM, Dugmore TIJ, Matharu AS, Morones-Ramirez JR (2020) Antimicrobial activity of a silver-microfibrillated cellulose biocomposite against susceptible and resistant bacteria. Sci Rep 10:7281

Gelinas Y, Prentice KM, Baldock JA, Hedges J (2001) An improved thermal oxidation method for the quantification of soot/graphite carbon in sediments and soils. Environ Sci Technol 21:3519-3525

Gurunathan S (2019) Rapid biological synthesis of silver nanoparticles and their enhanced antibacterial effects against Escherichia fergusonii and Streptococcus mutans. Arab J Chem 12:168-180

Hardonnière K, Saunier E, Lemarié A, Fernier M, Gallais I, HélièsToussaint C, Mograbi B, Antonio S, Bénit P, Rustin P, Janin M, Habarou F, Ottolenghi C, Lavault M-T, Benelli C, Sergent O, Huc L, Bortoli S, Lagadic-Gossmann D (2016) The environmental carcinogen benzo[a]pyrene induces a Warburg-like metabolic reprogramming dependent on NHE1 and associated with cell survival. Sci Rep 6:30776

Hassan SSM, Abdel-Shafy HI, Mansour MSM (2018) Removal of pyrene and benzo(a)pyrene micropollutant from water via adsorption by green synthesized iron oxide nanoparticles. advances in Natural Sciences. Nanosci Nanotechnol 9(1):015006

Huang W, Wang J-Q, Song H-Y, Zhang Q, Liu G-F (2017) Chemical analysis and in vitro antimicrobial effects and mechanism of action of Trachyspermum copticum essential oil against Escherichia coli. Asian Pac J Trop Med 10:663-669

IARC, International Agency for Research on Cancer, (2010) IARC Monographs on the Evaluation of Carcinogenic Risks to Humans. (Lyon: World Health Organization) 92, 1-853

Ilyas M, Ahmad W, Khan H (2021) Utilization of activated carbon derived from waste plastic for decontamination of polycyclic aromatic hydrocarbons laden wastewater. Water Sci Technol 84:609-631

Ishihara M, Nguyen VQ, Mori Y, Nakamura S, Hattori H (2015) Adsorption of silver nanoparticles onto different surface structures of chitin/chitosan and correlations with antimicrobial activities. Int J Mol Sci 16:13973-13988

Jaworski S, Wierzbicki M, Sawosz E, Jung A, Gielerak G, Biernat J, Jaremek H, Łojkowski W, Woźniak B, Wojnarowicz J, Stobiński L, Małolepszy A, Mazurkiewicz-Pawlicka M, Łojkowski M, Kurantowicz N, Chwalibog A (2018) Graphene oxide-based nanocomposites decorated with silver nanoparticles as an antibacterial agent. Nanoscale Res Lett 13:116

Jyoti K, Baunthiyal M, Singh A (2016) Characterization of silver nanoparticles synthesized using Urtica dioica Linn. leaves and their synergistic effects with antibiotics. J Rad Res Appl Sci 9:217-227

Khan E, Khaodhir S, Rotwiron P (2007) Polycyclic aromatic hydrocarbon removal from water by natural fiber sorption. Water Environ Res 79:901-911

Kim JS, Kuk E, Yu KN, Kim J-H, Park SJ, Lee HJ, Kim SH, Park YK, Park YH, Hwang C-Y, Kim Y-K, Lee Y-S, Jeong DH, Cho M-H (2007) Antimicrobial effects of silver nanoparticles. Nanomed Nanotechnol Biol Med 3:95-101 
Kulthanan K, Nuchkull P, Varothai S (2013) The pH of water from various sources: an overview for recommendation for patients with atopic dermatitis. Asia Pac Allergy 3:155-160

Kurwadkar S, Hoang TV, Malwade K, Kanel SR, Harper WF, Struckhoff G (2019) Application of carbon nanotubes for removal of emerging contaminants of concern in engineered water and wastewater treatment systems. Nanotechnol Environ Eng 4(1):1-16

Lamichhane S, Bal Krishna KC, Sarukkalige R (2016) Polycyclic aromatic hydrocarbons (PAHs) removal by sorption: A review. Chemosphere 148:336-353

Li H, He N, Cheng C, Dong H, Wen J, Wang X (2020) Antimicrobial polymer contained adsorbent a promising candidate with remarkable anti-biofouling ability and durability for enhanced uranium extraction from seawater. Chem Eng J 388:124273

Liikanen R, Yli-Kuivila J, Tenhunen J, Laukkanen R (2006) Cost and environmental impact of nanofiltration in treating chemically pretreated surface water. Desalination 201:58-70

Liu L, Liu J, Wang Y, Yan X, Sun DD (2011) Facile synthesis of monodispersed silver nanoparticles on graphene oxide sheets with enhanced antibacterial activity. New J Chem 35:1418-1423

Loan Khanh L, Thanh Truc N, Tan Dat N, Thi Phuong NN, van Toi V, Thi Thu HN, Ngoc Quyen T, Thi Thanh LT, Thi Hiep N (2019) Gelatin-capped composites of silver nanoparticles and curcumin: characterization, antibacterial and antioxidant study. Sci Technol Adv Mater 20:276-290

Loo YY, Rukayadi Y, Nor-Khaizura M-A-R, Kuan CH, Chieng BW, Nishibuchi M, Radu S (2018) In vitro antimicrobial activity of green synthesized silver nanoparticles against selected gramnegative foodborne pathogens. Front Microbiol. https://doi.org/ 10.3389/fmicb.2018.01555

Maizura M, Fazilah A, Norziah MH, Karim AA (2007) Antibacterial activity and mechanical properties of partially hydrolyzed sago starch-alginate edible film containing lemongrass oil. J Food Sci 72:C324-C330

McBirney SE, Trinh K, Wong-Beringer A, Armani AM (2016) Wavelength-normalized spectroscopic analysis of Staphylococcus aureus and Pseudomonas aeruginosa growth rates. Biomed Opt Express 7:4034-4042

Mehta R, Saha NK, Bhattacharya A (2017) Pretreatment of agriculture field water for improving membrane flux during pesticide removal. Appl Water Sci 7:3281-3290

Minkina T, Vasilyeva G, Popileshko Y, Bauer T, Sushkova S, Fedorenko A, Antonenko E, Pinskii D, Mazarji M, Ferreira CSS (2021) Sorption of benzo[a]pyrene by Chernozem and carbonaceous sorbents: comparison of kinetics and interaction mechanisms. Environ Geochem Health. https://doi.org/10.1007/ s10653-021-00945-8

Miren J, Aurora M-B, Ulrich K, Tomas G-A (2018) Smart and multifunctional materials and their possible application in façade systems. J Facade Des Eng 6:19-33

Mojahed F, Dehghanpour S, Alizadeh M, Mahmoudi A (2011) Wet chemical synthesis of oleylamine-capped silver nanoparticles by a fast and facile reproducible method. Synth React Inorg, Met-Org, Nano-Met Chem 41:664-670

Munyeza CF, Osano AM, Maghanga JK, Forbes PBC (2020) Polycyclic aromatic hydrocarbon gaseous emissions from household cooking devices: a kenyan case study. Environ Toxicol Chem 39:538-547

Myneni SCB (2019) Chemistry of natural organic matter-the next step: commentary on a humic substances debate. J Environ Qual 48:233-235

Nguyen TH, Sabbah I, Ball WP (2004) Sorption nonlinearity for organic contaminants with diesel soot: method development and isotherm interpretation. Environ Sci Technol 38:3595-3603

Ololade IA, Adeola AO, Oladoja NA, Ololade OO, Nwaolisa SU, Alabi AB, Ogungbe IV (2018) In-situ modification of soil organic matter towards adsorption and desorption of phenol and its chlorinated derivatives. J Environ Chem Eng 6:3485-3494

Padilla-Cruz AL, Garza-Cervantes JA, Vasto-Anzaldo XG, GarcíaRivas G, León-Buitimea A, Morones-Ramírez JR (2021) Synthesis and design of $\mathrm{Ag}-\mathrm{Fe}$ bimetallic nanoparticles as antimicrobial synergistic combination therapies against clinically relevant pathogens. Sci Rep 11:5351

Pang Z, Raudonis R, Glick BR, Lin T-J, Cheng Z (2019) Antibiotic resistance in Pseudomonas aeruginosa: mechanisms and alternative therapeutic strategies. Biotechnol Adv 37:177-192

Pazos-Ortiz E, Roque-Ruiz JH, Hinojos-Márquez EA, López-Esparza J, Donohué-Cornejo A, Cuevas-González JC, Espinosa-Cristóbal LF, Reyes-López SY (2017) Dose-dependent antimicrobial activity of silver nanoparticles on polycaprolactone fibers against gram-positive and gram-negative bacteria. J Nanomater. https:// doi.org/10.1155/2017/4752314

Pérez-Gregorio MR, García-Falcón MS, Martínez-Carballo E, SimalGándara J (2010) Removal of polycyclic aromatic hydrocarbons from organic solvents by ashes wastes. J Hazard Mater 178:273-281

Prakash P, Gnanaprakasam P, Emmanuel R, Arokiyaraj S, Saravanan M (2013) Green synthesis of silver nanoparticles from leaf extract of Mimusops elengi, Linn. for enhanced antibacterial activity against multi drug resistant clinical isolates. Colloids Surf B 108:255-259

Proft T, Baker EN (2009) Pili in Gram-negative and Gram-positive bacteria - structure, assembly and their role in disease. Cell Mol Life Sci 66:613. https://doi.org/10.1007/s00018-008-8477-4

Quintero-Quiroz C, Botero LE, Zárate-Triviño D, Acevedo-Yepes N, Escobar JS, Pérez VZ, Cruz Riano LJ (2020) Synthesis and characterization of a silver nanoparticle-containing polymer composite with antimicrobial abilities for application in prosthetic and orthotic devices. Biomater Res 24:13

Ran Y, Sun K, Ma X, Wang GH, Grathwohl P, Zeng EY (2007) Effect of condensed organic matters on solvent extraction and aqueous leaching of PAHs based in soils and sediments. J Environ Poll 43:111-123

Schinwald A, Murphy FA, Jones A, MacNee W, Donaldson K (2012) Graphene-based nanoplatelets: a new risk to the respiratory system as a consequence of their unusual aerodynamic properties. ACS Nano 6:736-746

Schoonraad G, Madito MJ, Manyala N, Forbes PBC (2020) Synthesis and optimisation of a novel graphene wool material by atmospheric pressure chemical vapour deposition. J Mater Sci 55:545-564

Sears GW (1956) Determination of specific surface area of colloidal silica by titration with sodium hydroxide. Anal Chem 28:1981-1983

Sha L, Guanying C, Paras NP, Mark TS (2011) Synthesis of Monodisperse $\mathrm{Au}, \mathrm{Ag}$, and AuAg alloy nanoparticleswith tunable size and surface plasmon resonance frequency. Chem Mater 23:4098-4101

Sillanpää M, Ncibi MC, Matilainen A (2018) Advanced oxidation processes for the removal of natural organic matter from drinking water sources: a comprehensive review. J Environ Manage 208:56-76

Tran M-H, Jeong HK (2015) Synthesis and characterization of silver nanoparticles doped reduced graphene oxide. Chem Phys Lett 630:80-85

Vasileva SY, Olenin AY, Romanovskaya GI, Krutyakov YA, Pogonin VI, Korotkov AS, Zuev BK (2009) Adsorption preconcentration of pyrene by silver nanoparticles and its determination in aqueous solutions. J Anal Chem 64:1214-1220

Vazquez-Muñoz R, Meza-Villezcas A, Fournier PGJ, Soria-Castro E, Juarez-Moreno K, Gallego-Hernández AL, Bogdanchikova N, Vazquez-Duhalt R, Huerta-Saquero A (2019) Enhancement of antibiotics antimicrobial activity due to the silver nanoparticles impact on the cell membrane. PLOS ONE, 14, e0224904 
Wang L, Niu J, Yang Z, Shen Z, Wang J (2008) Effects of carbonate and organic matter on sorption and desorption behavior of polycyclic aromatic hydrocarbons in the sediments from Yangtze River. J Hazard Mater 154:811-817

Wang W, Wang Z, Liu J, Zhang Z, Sun L (2017) Single-step one-pot synthesis of graphene foam/TiO2 nanosheet hybrids for effective water treatment. Sci Rep 7:43755

Wang S, Li X, Liu Y, Zhang C, Tan X, Zeng G, Song B, Jiang L (2018) Nitrogen-containing amino compounds functionalized graphene oxide: Synthesis, characterization and application for the removal of pollutants from wastewater: a review. J Hazard Mater 342:177-191

Xiu ZM, Zhang QB, Puppala HL, Colvin VL, Alvarez PJ (2012) Negligible particle-specific antibacterial activity of silver nanoparticles. Nano Lett 12:4271-4275

Yakout SM, Daifullah AAM (2013) Removal of selected polycyclic aromatic hydrocarbons from aqueous solution onto various adsorbent materials. Desalin Water Treat 51:6711-6718

Yang K, Chen B, Zhu L (2015) Graphene-coated materials using silica particles as a framework for highly efficient removal of aromatic pollutants in water. Sci Rep 5:11641

Yerushalmi L, Nefil S, Hausler R, Guiot SR (2006) Removal of pyrene and benzo(a)Pyrene from contaminated water by sequential and simultaneous ozonation and biotreatment. Water Environ Res 78:2286-2292

Yuan P, Li X, Wang W, Liu H, Yan Y, Yang H, Yue Y, Bao X (2018) Tailored design of differently modified mesoporous materials to deeply understand the adsorption mechanism for polycyclic aromatic hydrocarbons. Langmuir 34:15708-15718

Zhang C, Wu L, Cai D, Zhang C, Wang N, Zhang J, Wu Z (2013) Adsorption of polycyclic aromatic hydrocarbons (fluoranthene and anthracenemethanol) by functional graphene oxide and removal by ph and temperature-sensitive coagulation. ACS Appl Mater Interf 5:4783-4790

Zhang W, Yang Z-Y, Cheng X-W, Tang R-C, Qiao Y-F (2019) Adsorption, antibacterial and antioxidant properties of tannic acid on silk fiber. Polymers 11(6):970

Zhao G, Jiang L, He Y, Li J, Dong H, Wang X, Hu W (2011) Sulfonated graphene for persistent aromatic pollutant management. Adv Mater 23:3959-3963

Publisher's Note Springer Nature remains neutral with regard to jurisdictional claims in published maps and institutional affiliations. 